\title{
Human Immunodeficiency Virus (HIV)
}

\author{
German Advisory Committee Blood (Arbeitskreis Blut), Subgroup 'Assessment of Pathogens \\ Transmissible by Blood'
}

\section{Current Knowledge about the Pathogen}

\subsection{Characteristics of HIV}

The human immunodeficiency virus (HIV) is grouped to the genus Lentivirus within the family of Retroviridae, subfamily Orthoretrovirinae [1]. On the basis of genetic characteristics and differences in the viral antigens, HIV is classified into the types 1 and 2 (HIV-1, HIV-2). The immunodeficiency viruses of non-human primates (simian immunodeficiency virus, SIV) are also grouped to the genus Lentivirus. Epidemiologic and phylogenetic analyses currently available imply that HIV was introduced into the human population around 1920 to 1940 . HIV-1 evolved from non-human primate immunodeficiency viruses from Central African chimpanzees (SIVcpz) and HIV-2 from West African sooty mangabeys (SIVsm) [2-4].

\subsubsection{HIV-1}

\section{Genome Structure}

The HIV genome consists of two identical single-stranded RNA molecules that are enclosed within the core of the virus particle. The genome of the HIV provirus (see 1.1.3), also known as proviral DNA, is generated by the reverse transcription of the viral RNA genome into DNA, degradation of the RNA and integration of the double-stranded HIV DNA into the human genome. The DNA genome is flanked at both ends by LTR (long terminal repeat) sequences (fig. 1). The 5 ' LTR region codes for the promotor for transcription of the viral genes. In the direction 5 ' to $3^{\prime}$ the reading frame of the gag gene follows, encoding the proteins of the outer core membrane (MA, p17), the capsid protein (CA, p24), the nucleocapsid (NC, p7) and a smaller, nucleic acid-stabilising protein (fig. 1 and 3). The gag reading frame is followed by the pol reading frame coding for the enzymes protease (PR, p12), reverse transcriptase (RT, p51) and RNase H (p15) or RT plus RNase H (together p66) and integrase (IN, p32). Adjacent to the pol gene, the env reading frame follows from which the two envelope glycoproteins gp120 (surface protein, SU) and gp41 (transmembrane pro- tein, TM) are derived. In addition to the structural proteins, the HIV genome codes for several regulatory proteins: Tat (transactivator protein) and Rev (RNA splicing-regulator) are necessary for the initiation of HIV replication, while the other regulatory proteins Nef (negative regulating factor), Vif (viral infectivity factor), Vpr (virus protein $\mathrm{r}$ ) and $\mathrm{Vpu}$ (virus protein unique) have an impact on viral replication, virus budding and pathogenesis (overview in table 1) [5, 6]. HIV-2 codes for Vpx (virus protein $\mathrm{x}$ ) instead of $\mathrm{Vpu}$, which is partially responsible for the reduced pathogenicity of HIV-2 [7]. The genome structure of the immunodeficiency viruses of chimpanzees (SIVcpz) and gorillas (SIVgor) is identical to that of HIV-1 [8].

\section{Groups and Subtypes}

HIV-1 is subdivided into the groups $\mathrm{M}, \mathrm{N}[9]$, O und $\mathrm{P}[10,11]$ (fig. 2). On the basis of phylogenetic analysis, various chimpanzee viruses can be allocated in between groups $\mathrm{N}$ and $\mathrm{O}$ of humans and SIV of gorillas (SIVgor) in group P [2, 3, 12]. It is unresolved whether the group $\mathrm{P}$ chimpanzee virus was transmitted to human directly from chimpanzee or from gorilla.

HIV-1 group $M$ viruses are subdivided into subtypes A to D, F to $\mathrm{H}, \mathrm{J}$ and $\mathrm{K}$. In evolutionary terms, groups $\mathrm{A}$ and $\mathrm{D}$ seem to be the oldest viruses. Subtypes B and D are very closely related and therefore considered to be sub-subtypes. Recombinant HIV are derived from various subtypes and are named CRF (circulating recombinant form). Approximately $20 \%$ of group $\mathrm{M}$ viruses belong to these viruses [13]. For example, the previously described HIV subtype $\mathrm{E}$ is only unique regarding the gene for the envelope protein $(e n v)$, whereas all other parts of the genome are derived from HIV-1 M:A, and therefore has been renamed as HIV-1 M: CRF01_ $\mathrm{AE}$ [8]. The former subtype I is likewise a recombinant virus (CRF04_cpx) and therefore no longer contained in the A-K grouping. Up to now, more than 70 different epidemiologically stable CRF have been described $[8,14-16]$, and the development of additional CRF is to be expected.

Recombination, i.e. the exchange of entire gene sequences at unselected positions, is observed when a target cell is infected with two different HIV subtypes. Statistically, approximately 1 in 400

\section{KARGER \\ Fax +497614520714

\section{() 2016 S. Karger GmbH, Freiburg}

$1660-3796 / 16 / 0433-0203 \$ 39.50 / 0$ 
Table 1. Overview of HIV-1 proteins and their function

\begin{tabular}{|c|c|c|c|}
\hline Gene & $\operatorname{Size}^{*}$ & Protein & Function \\
\hline \multirow[t]{5}{*}{ gag } & & Pr55Gag & precursor of the inner structural proteins \\
\hline & $\mathrm{p} 24$ & capsid protein (CA) & formation of conical capsid \\
\hline & p17 & matrix protein (MA) & myristilated protein, forming the inner membrane layer \\
\hline & p7 & nucleoprotein (NC) & formation of the nucleoprotein/RNA complex \\
\hline & p6 & & involved in virus particle release \\
\hline \multirow[t]{5}{*}{ pol } & & Pr160GagPol & precursor of the viral enzymes \\
\hline & p10 & protease (PR) & $\begin{array}{l}\text { proteolytic cleavage of Gag }(\mathrm{Pr} 55) \text { and Gag-Pol (Pr160GagPol) precursor protein; release of } \\
\text { structural proteins and viral enzymes }\end{array}$ \\
\hline & $\mathrm{p} 51$ & reverse transcriptase (RT) & transcription of HIV RNA in proviral DNA \\
\hline & p15 (66) & RNase $\mathrm{H}$ & degradation of viral RNA in the viral RNA/DNA replication complex \\
\hline & p32 & integrase (IN) & integration of proviral DNA into the host genome \\
\hline \multirow[t]{3}{*}{ env } & & PrGp160 & precursor of the envelope proteins SU and TM, cleavage by cellular protease \\
\hline & gp120 & surface glycoprotein (SU) & attachment of virus to the target cell \\
\hline & gp41 & transmembrane protein (TM) & anchorage of gp120, fusion of viral and cell membrane \\
\hline tat & p14 & transactivator protein & activator of transcription of viral genes \\
\hline rev & p19 & RNA splicing regulator & regulates the export of non-spliced and partially spliced viral mRNA \\
\hline nef & $\mathrm{p} 27$ & negative regulating factor & $\begin{array}{l}\text { myristilated protein, influence on HIV replication, enhancement of infectivity of viral } \\
\text { particles, downregulation of CD4 on target cells and HLA cells on target }\end{array}$ \\
\hline vif & p23 & viral infectivity protein & critical for infectious virus production in vivo \\
\hline$v p r$ & p15 & virus protein $r$ & $\begin{array}{l}\text { component of virus particles, interaction with p6, facilitates virus infectivity, effect on the cell } \\
\text { cycle }\end{array}$ \\
\hline vpu & p16 & virus protein unique & efficient virus particle release, control of CD4 degradation, modulates intracellular trafficking \\
\hline$v p x$ & p15 & virus protein $\mathrm{x}$ & $\begin{array}{l}\text { interaction with p6 in virus particles, involved in early steps of virus replication of HIV-2, } \\
\text { component of virus particles }\end{array}$ \\
\hline tev & p26 & tat/rev protein & Tat-Env-Rev fusion protein, regulates the activity of Tat and Rev in nucleus \\
\hline
\end{tabular}

Fig. 1. Structure and organization of the

\begin{tabular}{llllllllllllllll}
0 & 1 & 2 & 3 & 4 & 5 & 6 & 7 & & 8 & & 9 & $k b$ \\
\hline
\end{tabular}
HIV-1 genome. Shown are the reading frames of the genes coding for structural and regulatory proteins (see table 1): LTR = long terminal repeat; $g a g=$ groupspecific antigen; $p o l=$ polymerase; env = envelope. In the case of the regulator genes, the proteins of tat and rev are composed of two gene regions. In HIV-2, $v p x$ corresponds to the $v p u$ gene. The $5^{\prime}$ and $3^{\prime}$ LTR nucleic acid sequences are not translated into protein. The genome consists of 9,2009,600 nucleotides in the case of HIV-1 and approximately 9,800 nucleotides in the case of HIV-2 (drawing: Lutz Gürtler).

newly produced virus particles is a recombinant [17]. Genetically new virus strains develop by recombination which can have a selection advantage within the host, like HIV-1 M:A/G (named CRF02_AG) in West Africa and B/C (CRF07_BC and CRF08_BC) in China [12, 13]. Recombinants between different HIV-1 groups have been observed, for example group $\mathrm{M}$ subtype $\mathrm{A}$ and group $\mathrm{O}$ in Cameroon [18]. However, no recombination between HIV-1 and HIV-2 has yet been found. For group O virus isolates $[19,20]$ a grouping was proposed into subtypes I to VI or A to C, respectively $[21,22]$. However, no typical evolutionary tree like the one described for group $M$ viruses can be generated [23] (fig. 2). This points to an evolution of group $\mathrm{O}$ viruses that differs from that of 
Fig. 2. Schema of the phylogenetic tree of human and simian Lentiviruses using the analysis of a pol region of Lentiviruses. On the right side (in red) HIV- 1 is displayed with its groups $\mathrm{M}, \mathrm{N}, \mathrm{O}$ and $\mathrm{P}$ (dotted lines). Branching within groups $\mathrm{M}$ and $\mathrm{O}$ indicates the different subtypes. Groups $\mathrm{N}$ and $\mathrm{P}$ cannot be differentiated into subtypes. HIV-1 has developed from zoonotic transmission of different immunodeficiency viruses (SIV cpz) originating from chimpanzees belonging to Pan troglodytes troglodytes troglodytes (central chimpanzee) but not from Pan troglodytes schweinfurthii (eastern chimpanzee). SIVgor of gorillas (Gorilla gorilla) is phylogenetically grouped to HIV-1 group P and is therefore not listed. HIV-2 and its groups A to $\mathrm{H}$ (in blue) coincide phylogenetically with immunodeficiency viruses of mangabey ( $\mathrm{smm}=$ sooty mangabey monkey). The designation of additional SIVs: mnd = Mandril (Mandrillus sphinx $) ; \mathrm{drl}=$ Drill

(Mandrillus leucophaeus), col = colobus monkeys (Mantled guereza, Colobus guereza), gsn = greater spot nosed monkey (Cercopithecus nictitans), mon = Mona monkey (Cercopithecus mona); mus = Moustached gueneon (Cercopithecus cephus); deb = De Brazza's monkey (Cercopithecus neglectus); lho = group of L'hoesti monkeys (Cercopithecus l'hoesti); sun = sun tailed monkey (Cercopithecus solatus); syk = Sykes monkeys (Cercopithecus albogularis); tal = Gabon (Northern) talapoin (Miopithecus oguensis); wrc = western red colobus (Procolobus badius); agm = African green monkey (Chlorocebus tantalus, C aethiops, $C$ vervet). The schema of the phylogenetic tree of primate Lentiviruses (SIV, HIV) was developed according to publications by Sharp and Hahn, 2011 [3]; Santiago et al., 2005 [32]; Aulicino et al., 2012 [110]; Aghokeng et al., 2010 [218] and Holmes et al., 1995 [219].

Fig. 3. Schematic view of the HIV particle, corresponding electron micrograph (right) and immunoblot bands (left). Gp = Glycoprotein; $\mathrm{p}=$ protein; $\mathrm{SU}=$ surface protein; $\mathrm{TM}=$ transmembrane protein; gp120 (precursor of SU and TM); RT = reverse transcriptase; $\mathrm{IN}=$ integrase; $\mathrm{CA}=$ capsid protein; $\mathrm{MA}=$ matrix protein; $\mathrm{PR}=$ protease; $\mathrm{NC}=$ nucleic acid binding protein; LI $=$ link protein. MHCs (major histocompatibility complexes) are HLA antigens. Localisation of the genes coding for the different structural, enzyme and regulatory proteins are shown in figure 1. Table 1 summarises the function of the different proteins. Graphic Hans Gelderblom, Robert Koch Institute, Berlin.

group $\mathrm{M}$ viruses after both were first transmitted to humans [4] Because only approximately 15 individuals infected with group $\mathrm{N}$ [9] and 2 with group P [23] have been reported so far, a compilation of a phylogenetic tree for these viruses is not indicated.

\section{Particle Structure}

The mature HIV particle is round, measures approximately 100 $\mathrm{nm}$ in diameter, with an outer lipid membrane as its envelope (fig. 3). The envelope contains 72 knobs, composed of trimers of the Env proteins. The trimers of gp120 surface protein (SU) are an- chored to the membrane by the trimers of the transmembrane protein gp41 (TM) [24]. Conformation-dependent neutralising epitopes are found on the gp120 protein. These are present on the native protein but are only partially expressed on the unfolded denatured protein [25]. The viral envelope is composed of a lipid bilayer and, in mature virus particles, the envelope proteins $\mathrm{SU}$ and TM. It covers the symmetrical outer capsid membrane which is formed by the matrix protein (MA, p17). The conical capsid is assembled from the inner capsid protein p24 (CA) [26]. Depending on the section plane, the capsid appears as a cone, a ring or an el- 
lipse in electron micrographs (fig. 3). The tapered pole of the capsid is attached to the outer capsid membrane. Two identical molecules of viral genomic RNA are located inside the capsid and several molecules of the viral enzymes RT/RNase $\mathrm{H}$ and IN bound to the nucleic acid [1]. Also present in virus particles are oligopeptides that are generated after release from the cell during the maturation of virions by proteolytic processing of the precursor proteins (p55, p160).

Maturation of the HIV particle takes place by cleavage of the Gag and Gag/Pol precursor proteins (p55, p160) into individual proteins at the end of the budding process and during release of virions from the cell. In electron microscopic investigations, loss of surface projections (SU trimers) as a result of shear forces - also known as shedding - can be observed after release [27]. Particles free of gp120 are no longer infective [28].

\section{Regulatory Proteins}

Tat accelerates the availability of viral RNA for virus production approximately 100 -fold. Tat binds to the TAR sequence of viral RNA, but not to cellular RNA. Furthermore, Tat is able to transactivate additional HIV genomes present in the cell. Tat expression is induced by Tat but also by cytokines such as p65 and NFkB [29].

Rev is responsible for the splicing length of the newly formed HIV RNAs. This enables the production of regulatory proteins early during replication, followed by translation of structural proteins in the late stage of the replication cycle.

Nef has a negative effect on the presentation of CD4 molecules on the cell surface. Therefore, the membrane of the infected cell becomes deficient in CD4 and cannot be superinfected by additional HIV (see below). The loss of CD4 decelerates the cellular immune reaction against the infected cell. Moreover, Nef enhances pathogenicity in vivo and is required for the progression of the infection [5]. HIV-1 Nef consists of a lower number of amino acids and has a higher capacity to increase the pathogenicity of HIV-1 compared to HIV-2.

Additional regulatory proteins are Vif, Vpr and Vpu which influence the rate of the production of virus particles [8, 30, 31].

\subsubsection{HIV-2}

HIV-2 is closely related to SIV-2 of mangabey monkeys in West Africa (SIVsmm) (fig. 2). Molecular biological methods are not capable of distinguishing HIV-2 isolates of groups A-H from isolates of mangabeys [32]. The evolution of HIV-1 group $\mathrm{M}$ in humans is distinct from that of HIV-1 group O and HIV-2 [33]. Additional primate lentiviruses were identified in a variety of African nonhuman primates like African green monkeys (SIVagm), drills (SIVdrl), mandrill (SIVmnd), Sykes monkey (SIVsyk), Colobus monkeys (SIVcol) and greater spot-nosed monkey (SIVgsn), but none in Asian or South American monkeys (fig. 2) [12, 33-35]. So far, none of these viruses have been transmitted to humans to induce infection chains.

HIV-2 is morphologically indistinguishable from HIV-1 [12]. The HIV-2 A group is subdivided into A1 and A2 [36, 37]. Due to distinct differences between HIV-1 and HIV-2 in the antigenicity of the viral proteins and in the genome structure, HIV-2-specific diagnostic tools are required. NAT tests for quantification of HIV-2 nucleic acids have been commercially available since 2012 [38]. As mentioned above, HIV-2 usually has a lower pathogenic potential than HIV-1.

\subsubsection{Infection of Human Cells}

The initial steps of infection of a cell are characterised by complex protein-protein interactions. The surface glycoprotein gp120 of the mature HIV particle binds to the CD4 receptor on the host cell. All CD4-positive cells such as Thelper cells, macrophages, dendritic cells and astrocytes are susceptible to HIV. After attachment to the CD4 molecule via the C4-domain of gp120, a conformational change in CD4 and gp120 occurs, opening up an additional site for gp120 to enable binding to the co-receptor, i.e. chemokine receptor 5 (CCR5) or chemokine receptor 4 (CXCR4 or fusin) on the cell surface $[39,40]$. Binding of gp120 to CD4 and to the co-receptor triggers an additional conformational change in gp120 and subsequently in gp41 $[1,41]$. The $\mathrm{N}$-terminus of gp41 is presented on the viral membrane, forms a channel and, due to its high hydrophobicity, inserts into the plasma membrane of the target cell. Fusion of cell membrane and viral envelope is then completed.

Fusion of the viral and cellular membranes leads to translocation of the viral capsid into the cytoplasm. The capsid is taken up by an endosome, and a change in the $\mathrm{pH}$ value in the phagosome induces the release of the capsid contents into the cytoplasm [42]. Activation of reverse transcriptase (RT) takes place in the cytoplasm. HIV RT transcribes the single-strand HIV RNA genome into DNA (complementary DNA or cDNA). In parallel to DNA synthesis, the RNA strand is degraded enzymatically by RNase $\mathrm{H}$, followed by conversion of single-stranded cDNA into doublestranded DNA (proviral DNA) by the DNA-dependent DNA polymerase activity of RT [43]. This proviral DNA is transported via nucleopores into the cell nucleus in the form of a complex consisting of the integrase (IN) and linear or circular proviral DNA. The integrase then inserts at random the proviral genome into the human host cell genome. Integration of the proviral DNA finalises the HIV infection of the cell and the establishment of a persistent infection.

The proviral genome can be replicated together with and as part of the host cell genome during cell division (latent infection which seems to be rare). However, after activation of infected cells the LTR promotor of the proviral genome can serve as attachment site for cellular DNA-dependent RNA polymerases and a variety of transcription factors initiating the synthesis of viral mRNA and genomic RNA. The synthesis of full-length viral mRNA is regulated among others by Tat and maximally accelerated by Tat (p14) [44].

The attachment of HIV to a CD4-positive cell requires around 30 min up to $2 \mathrm{~h}$, the transcription of the viral RNA genome into the proviral DNA is completed after approximately $6 \mathrm{~h}$, and the integration into the host genome takes an additional $6 \mathrm{~h}$. After integration, the first virus particles are detectable after approximately $12 \mathrm{~h}$; i.e. approximately $24 \mathrm{~h}$ after infection the first progeny viruses are released from the infected cell. Because the viral RT has 
no proofreading activity, statistically one incorrect nucleotide per transcription round is incorporated into the proviral DNA. If HIV replication is unrestricted a daily turnover of $10^{8}-10^{9}$ viral particles is expected, i.e. newly produced by infected cells and destroyed by the immune system [45-47]. Assuming a mutation rate of 1 in $10^{4}$ nucleotides per genome during one replication cycle, a broad spectrum of various quasispecies can therefore develop in a patient in the course of time. Since epitopes for neutralising antibodies are also affected by mutation, these quasispecies are able to continually evade the immune system, infect new cells and therefore maintain HIV production [25, 29]. Not all nucleotide changes result in the exchange of an amino acid. However, mutations in essential regions of the structural proteins or influencing active centres of enzymes give rise to replication-incompetent HIV mutants.

Infected $\mathrm{T}$ lymphocytes are eliminated with a half-life of 2-4 days from the blood of an HIV-infected person by cytotoxic HIV components, lysis of virus-producing cells or by cytotoxic T lymphocytes as part of the immune response [48, 49]. Since HIV-infected $\mathrm{T}$ helper cells are also lysed and the production of such cells is inhibited simultaneously, a gradual decline of T helper cells is observed. HIV-specific proteins like Nef and Tat are responsible for insufficient maturation and replacement of T helper cells [29]. Therefore, part of the newly produced $\mathrm{T}$ helper lymphocytes do not develop normal functions [47]. After a long-lasting HIV infection the continuous loss of $\mathrm{T}$ helper lymphocytes results in immunodeficiency. HIV integrated into the host genome of long-lived cells like macrophages, astrocytes or memory $\mathrm{T}$ cells can persist in the latent stage for several years (half-life of certain target cells is 7 years). Activation of such cells results in the production of infectious HIV particles.

\subsubsection{Susceptibility to Inactivation and Stability of HIV under} Environmental Conditions

The lipid envelope primarily characterises the stability of HIV. HIV is stable for several hours at a pH between 3 and 10 [50, 51]. HIV is sensitive against disinfectants. Treatment with $20 \%$ ethanol already somewhat reduces the titres of infectious virus, whereas $\mathrm{HIV}$ is efficiently inactivated within minutes by treatment with $70 \%$ ethanol, $50 \%$ isopropanol, $4 \%$ formaldehyde or peracetic acid as well as strong detergents like sodium dodecyl sulphate (SDS), NP-40 or Triton X-100 at a concentration of $\geq 1 \%[50,52]$.

HIV is stable over several hours against the influence of physical conditions like ultraviolet light, gamma irradiation or ultrasonic waves $[53,54]$. In contrast to other viruses, treatment of platelet concentrates with UVC light reduced HIV titres only slightly [55].

\section{Temperature-Dependent Inactivation}

The half-life ( $\mathrm{t} / 2)$ of HIV in solution is approximately $30 \mathrm{~min}$ at $56^{\circ} \mathrm{C}, 1 \mathrm{~min}$ at $60^{\circ} \mathrm{C}$ and less than $1 \mathrm{~s}$ at temperatures above $65^{\circ} \mathrm{C}$. Treatment of lyophilised HIV preparations at $100^{\circ} \mathrm{C}$ (dry heat) for $10 \mathrm{~min}$ inactivates HIV completely [56]. At lower temperatures HIV is relatively stable: $\mathrm{t} / 2$ is at $20^{\circ} \mathrm{C}$ approximately $9 \mathrm{~h}$, at $4{ }^{\circ} \mathrm{C}$ several months and below $-70^{\circ} \mathrm{C}$ indefinitely. At $-20^{\circ} \mathrm{C}$, a slight but continuous decline in the titre of HIV occurs (reduction of the genomic titre by approximately 15,000 copies/year) and degradation of HIV RNA. Therefore, specimens preserved for forensic purposes should be stored at a temperature below $-20{ }^{\circ} \mathrm{C}$.

\section{Half-Life Time in Blood and Plasma}

At body temperature, $\mathrm{t} / 2$ of HIV is approximately 2 days [45] and at $4{ }^{\circ} \mathrm{C}$ approximately 1 month. Therefore in a blood donation only a titre reduction of 1.5 half-lives is to be expected for a virus load of $100,000\left(10^{5}\right)$ particles/ml at the end of the shelf life after storage for 6 weeks at $4{ }^{\circ} \mathrm{C}$. In EDTA blood and EDTA plasma HIV RNA appeared to be stable, and a reduction of RNA titres of $<0.5$ $\log _{10}$ was determined after incubation at $4{ }^{\circ} \mathrm{C}$ for 7 days, at $25^{\circ} \mathrm{C}$ for 3 days and at $30^{\circ} \mathrm{C}$ for 2 days [57]. Taking into consideration that one human infectious dose (HID) corresponds to approximately 500-1,000 HIV particles, a small amount of transfused blood is sufficient to transmit an HIV infection, although exceptions were observed occasionally [58].

The infectivity of HIV particles in lymphocytes is variable. It has to be assumed that processed HIV in lymphocytes is inactivated more rapidly than in plasma. Inactivation of HIV was determined in cultured cells after 2 days [47], but it has to be assumed that intracellular HIV will be inactivated only after incubation for several weeks at $4{ }^{\circ} \mathrm{C}$. In dendritic cells HIV can remain infectious for several weeks [41]. In lyophilised plasma or factor concentrates, $\mathrm{HIV}$ is stable at room temperature for years in the presence of high protein concentrations.

\subsection{Infection and Infectious Diseases}

HIV is able to enter the body via intact mucous membranes, eczematous or injured skin or mucosa and by parenteral inoculation. When transmitted by sexual contact, HIV attaches first to dendritic cells (e.g. Langerhans cells) or macrophages/monocytes; HIV using CCR-5 (R5 viruses) as a co-receptor is then preferentially replicated [59]. HIV is taken up by macrophages and replicated [60] as shown for M cells in the mucosa [61]. HIV exposure to blood cells can result in the direct infection of $\mathrm{T}$ helper cells and the transmission of R5 and X4 viruses (using CXC4 receptor as a co-receptor) [62]. As mentioned above, $1 \mathrm{HID}$ is equivalent to approximately 500-1,000 HIV particles, with a higher dose required for infection via mucous membranes compared to infection via the bloodstream, e.g. by needle stick injury. The majority of new HIV infections are still transmitted sexually. Another epidemiologically relevant route is parenteral administration of drugs and also snorting of drugs with epistaxis.

One to two days after infection HIV can be detected in regional lymphatic tissue [63] and within 5-6 days in regional lymph nodes. After 10-14 days post infection HIV can be detected in the whole body, including the nervous system. Differences in the rate of dissemination of HIV in the body have been observed, depending on the primary target cells infected, e.g. in tonsils or in rectal mucosa [64]. Within an infected organism, distinct compartments can be distinguished by means of virus concentration; however, no 
Fig. 4. Diagram of the temporal course of an untreated HIV infection. The time scale is initially weeks (acute phase), then months and finally years (stages 2 and 3). The key feature of viraemia is the undulation after the initial uninhibited HIV replication. The CD4 cell count decreases over time despite repeated recovery phases. HIV antibodies remain measurable for life, and the decrease of antibody response in stages 2 and 3 results from loss of core antibodies (anti p55, p24 and p17). The overall interval from infection with the virus to the onset of AIDS may vary without therapy from 2 to 25 years or longer. Graphic Lutz Gürtler.

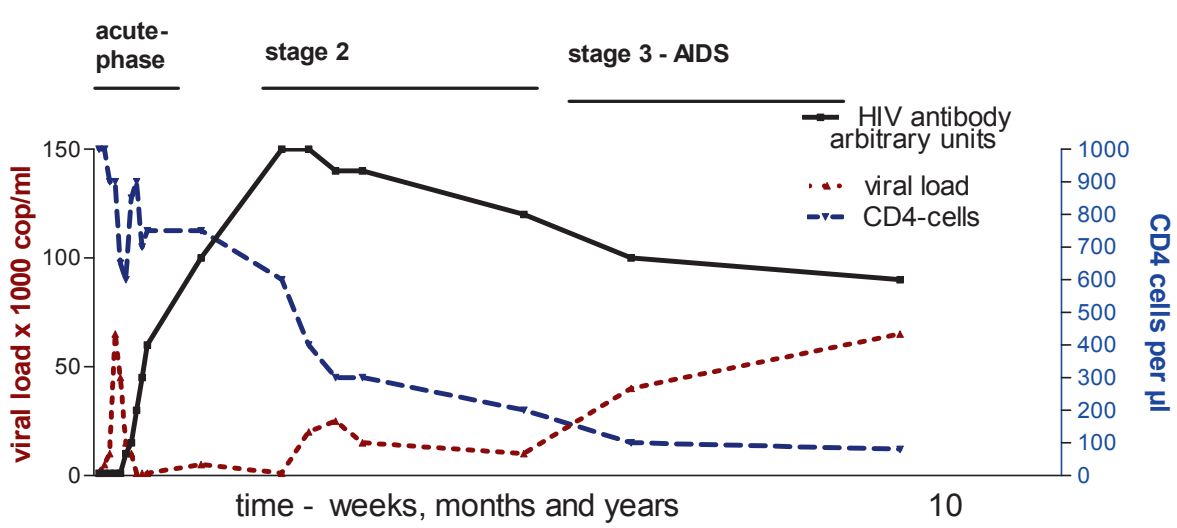

correlation between virus concentrations in the different compartments is obvious. HIV-relevant compartments are blood and the cerebrospinal and genital systems (ejaculate or vaginal secretion) $[65,66]$.

Transmission of HIV via blood or transplanted organs, including bone, is possible from about days 5-6 after infection of the donor. Mother-to-child transmission has been demonstrated from the 12th week of gestation, but transmission occurs predominantly $(>90 \%)$ in the final trimester and particularly shortly before or during birth [67]. HIV can be transmitted via breast milk [68].

With the onset of the humoral immune response against HIV after 3-6 weeks, variable clinical symptoms can be observed in the majority of infected persons $[5,69]$, with fever, lymph node enlargement, fatigue, malaise, rash with small, only slightly raised lesions and/or gastrointestinal symptoms. These symptoms are nonspecific and are also found in other viral infections such as EBVand $\mathrm{CMV}$-induced mononucleosis or influenza. Acute neuropathy is common in the acute phase. The symptoms persist for 2-6 weeks. This initial symptomatic phase is usually followed by an asymptomatic phase or one with occasional symptoms which can last for many years.

At the beginning of the infection virus titres of $10^{5}-10^{9}$ are reached in the blood, in exceptional cases up to $10^{14}$ genome copies/ml are observed (fig. 4) [69]. Therefore blood donations are highly infectious during this phase. During the asymptomatic phase the viral load may drop to $<10^{2}$ genome copies/ml or to undetectable levels. However, in this phase blood and cervicovaginal secretions or seminal fluids of infected persons are still infectious. From day 11 post infection HIV RNA can be detected in blood [70], and after 2 weeks HIV DNA can be found in blood lymphocytes [71]. In leucocytes from HIV-infected long-term non-progressors (LTNP) or elite controllers [72], who have no measureable viraemia, proviral HIV DNA can be determined after enrichment and stimulation of lymphocytes [73-75].

Depending on the immune response and the test systems used, the commercially available antibody screening tests are able to detect HIV-specific antibodies in the plasma approximately as of the third week post infection, typically after $4-5$ weeks and in the case of a delayed immune response after 8 weeks (see 1.4) [70,71]. At the beginning of the immune response low titres of $\operatorname{IgM}$ and $\operatorname{IgG}$ antibodies are detectable that are mainly directed against p24 and the surface glycoproteins gp120 and gp41. Subsequently, highavidity IgG antibodies against all HIV proteins are developed, typically within 1-3 weeks. A specific T-cell response is induced against a variety of epitopes of HIV proteins [76].

Like in other virus infections, the early immune response leads to an IgM antibody response that can persist for months [5]. Part of the antibodies have neutralising capacity and are directed against the glycoproteins gp120, gp41 or the group-specific proteins $\mathrm{p} 24 / \mathrm{p} 17$ of the infecting virus. A high portion of the neutralising antibodies is directed against the V3 loop of gp120. Such antibodies are strain-specific and are not able to sufficiently eliminate all HIV quasispecies which are continuously produced in the infected individual $[25,77,78]$. Under the pressure of the immune response, viruses with a variable V3 loop are selected. The V3 loop is the region of the gp120 protein (hypervariable region) in which high numbers of mutations are observed, resulting in amino acid exchanges. No serologic subtype differentiation is possible, but this can be achieved by determining the subtype-specific amino acid sequences of the C2V5 region of gp120 [8].

In the course of the HIV infection and depending on the number of CD4 cells, at first unspecific symptoms can be observed. These can include short episodes of fever, diarrhoea, malaise, fatigue and loss of weight (symptoms of the so-called AIDS-related complex, ARC). When immunodeficiency progresses, usually observed when the CD4 cell numbers are $<300 / \mu l$, the immune response is weakened and opportunistic infections and neoplasms develop. Characteristic features of an HIV infection are periods of good health followed by periods of illness which become more frequent and longer-lasting in the course of the infection $[79,80]$. Time to occurrence of apparent symptoms of immunodeficiency varies from 2 to 25 years or more (fig. 4). As mentioned above, impairment of neurologic and cerebral functions can emerge at any stage of infection.

Frequently occurring opportunistic pathogens are Toxoplasma gondii, Cryptosporidium parvum, Pneumocystis jirovecii, Mycobacterium tuberculosis and atypical mycobacteria, Salmonella spec., pneumococci, human polyomavirus JC, cytomegalovirus (CMV) and herpes simplex virus (HSV). Typical neoplasms observed in HIV infections are Kaposi's sarcoma associated with the human herpes virus type 8 (HHV-8), non-Hodgkin's lymphomas, i.e. Epstein-Barr virus(EBV)-associated B-cell lymphoma and car- 
cinomas of the penis, the anus and the cervix induced by human papillomaviruses (HPV). Patients with HIV infections lasting for years develop marasmus which is a characteristic outward manifestation of untreated patients [5]. Concurrent infection with hepatitis $\mathrm{C}$ virus (HCV) results in faster progression of both virus-induced diseases [81-83]. Some HIV-infected patients develop characteristic atrophic skin alterations or seborrhoeic eczema that are visible manifestations of the HIV infection. Likewise at an early stage of the infection changes of the oral mucosa are detectable, with gingival retraction and deep periodontal lesions as well as hairy leucoplakia on the lateral rim of the tongue or on the buccal mucosa [84].

WHO and CDC classify HIV-infected individuals into categories $\mathrm{A} 1-\mathrm{C} 3$ on the basis of the clinical picture and the $\mathrm{CD} 4$ cell count [85]. Stage A is asymptomatic, stage B denotes the range of mild symptoms up to symptoms of the ARC and stage C the AIDSdefining illness. Subdivision includes the CD 4 cell count. In stage 1 the CD 4 cell count in plasma is over $500 / \mu$ l, in stage 2 between 499 and $200 / \mu \mathrm{l}$ and in stage 3 below $200 / \mu \mathrm{l}$, respectively.

\subsection{Epidemiology}

According to present knowledge, the spread of HIV started at the beginning of the 20th century $[4,86]$. Zoonotic transmission of SIVcpz from chimpanzees (Pan troglodytes troglodytes) occurred for HIV-1 group $\mathrm{M}$ and group $\mathrm{O}$ around 1920 and for HIV-1 group $\mathrm{N}$ around $1960[23,33]$ in West Central Africa. HIV-2 was transmitted zoonotically from sooty mangabey (Cercocebus atys) to human in West Africa around 1940 [87]. Molecular genetic analyses suggest that HIV-1 was exported to Haiti probably in 1966 and arrived in North America approximately 2 years later [4, 88]. Since the mid-1980s the different HIV-1 M subtypes have been spreading, leading to a global pandemic. In contrast to HIV-1, HIV-2 initially remained restricted to West Africa because of its significantly lower infectivity. After HIV-2 was exported to Portugal and France probably during the mid-1960s, the spreading of HIV-2 with a low prevalence especially in Europe, South America and Asia is documented.

Globally, an estimated 35 million people were living with HIV in 2013 [89]. Since 1999 the number of new infections has been decreasing continuously, and for 2013 a number of 1.9 million newly infected persons was estimated. About three quarters of HIV-infected persons live in Sub-Saharan Africa, and also about two-thirds of the reported new infections originate from this region. The countries most affected by HIV with a high prevalence among 15- to 49-year-olds are Swaziland (approximately 27\%), Lesotho (approximately 23\%) and Botswana (approximately 23\%).

\subsubsection{Germany}

The data on the HIV epidemic in Germany are mainly based on the implemented obligatory reporting system. The Robert Koch Institute has to be notified directly and anonymously of a confirmed HIV infection according to $₫ 7$ para. 3 of the Protection
Against Infection Act (Infektionsschutzgesetz; IfSG). Reporting must be performed by the diagnosing laboratory (also the diagnosing blood establishment). The physician submitting the specimen receives a copy of the reporting form. The physician is required to supply demographic, anamnestic and clinical data which are not available to the laboratory. The completed reporting form is sent directly to the Robert Koch Institute. To recognise multiple reports on the same patient in this process, an anonymity-preserving casebased encryption is used ( $\$ 10$ para. 2 IfSG).

For a description of the HIV epidemic, additional information is used which is available from the AIDS case registry, the AIDS and HIV fatality registry, the death statistics of the statistical offices of the 'Länder' and sales data for antiretroviral drugs from pharmacy clearing centres.

The available surveillance instruments provide data on specific aspects of the HIV epidemic. Therefore, the Robert Koch Institute regularly generates estimations of the course of the HIV epidemic, taking into account the available data and information from the various sources. Determination of the number of new HIV infections per time unit (HIV incidence) by means of official reporting data is not possible because the reports of HIV diagnoses do not allow direct conclusions about the date of infection. HIV incidence and HIV prevalence cannot be measured directly but only estimated by means of model projections.

At first, the estimated number of new HIV infections in all age groups has decreased significantly in the course of time up to the end of the 1990s, with peak values in the mid-1980s. From 2000 to around 2005 a significant increase of HIV infections was observed, with a plateau since 2006. The total number of 3,200 (95\% CI $3,000-3,400)$ new infections was estimated for 2013 showing differences in the number of infections in different groups affected [90-92]. The most affected group were men who have sex with men (MSM) with about $75 \%(2,400 / 3,200)$ of the total number of new HIV infections in 2013. Approximately 360 women (11.3\%) and 190 men (5.9\%) contracted an HIV infection by heterosexual contacts in Germany (hetero-domestic). In addition, HIV infections were observed in about 300 (9.4\%) intravenous drug users (IVD) [91]. The trends in the three main groups affected in Germany proceeded differently: the first peak of infections occurred simultaneously in the groups of MSM and IVD in the mid-1980s. In the following years up to the beginning of the 1990s, the number of new HIV infections decreased significantly in both groups. This trend continued in the group of IVD up to 2010 with a largely constant low level of new infections since 2001. Also in the group of MSM significantly fewer infections occurred during the 1990s. However, in the period between 2000 and 2006 a significant increase in HIV infections in MSM was observed and reached a considerably higher plateau in 2006. The estimated HIV incidence in MSM showed the highest value in the age group of 25- to 29-yearold men with 19 new HIV infections per 100,000 male inhabitants; assuming that $3 \%$ of the adult males are MSM, this value corresponds to approximately 6 new infections per 1,000 MSM [91, 92]. The number of those infected via heterosexual contacts (heterodomestic) in Germany has been rising significantly slower in the 
Table 2. Newly diagnosed HIV infections and modes of transmission in different European countries in 2012 (www.euro.who.int/_data/assets/pdf_file/ 0018/235440/e96953.pdf)

\begin{tabular}{|c|c|c|c|c|c|}
\hline Geographical area & WHO Europe & WHO Europe West & WHO Europe Centre & WHO Europe East & EU/EEA \\
\hline Number of reporting countries/countries & $51 / 53$ & $23 / 23$ & $15 / 15$ & $13 / 15$ & $30 / 31$ \\
\hline New HIV diagnoses reported & 55,494 & 27,315 & 3,715 & 24,464 & 29,381 \\
\hline New HIV diagnoses/100,000 inhabitants & 7.8 & 6.6 & 1.9 & 22 & 5.8 \\
\hline Percentage of 15- to 24-year-olds & $10.3 \%$ & $9.8 \%$ & $15.4 \%$ & $10.1 \%$ & $10.6 \%$ \\
\hline Proportion male/female & $2.1 / 1$ & $3.1 / 1$ & $4.5 / 1$ & $1.4 / 1$ & $3.2 / 1$ \\
\hline \multicolumn{6}{|l|}{ Mode of infection } \\
\hline Heterosexual $^{*}$ & $45.6 \%$ & $35.3 \%$ & $24.6 \%$ & $60.2 \%$ & $33.8 \%$ \\
\hline MSM & $22.8 \%$ & $41.7 \%$ & $26.2 \%$ & $1.2 \%$ & $40.4 \%$ \\
\hline Intravenous drug use & $17.8 \%$ & $5.1 \%$ & $7.3 \%$ & $33.6 \%$ & $6.1 \%$ \\
\hline Unknown & $12.3 \%$ & $17 \%$ & $36.9 \%$ & $3.2 \%$ & $18.7 \%$ \\
\hline
\end{tabular}

course of the epidemic than in the MSM and IVD groups. Since 2005 the number of new infections in heterosexually infected persons has remained on a constant level. The initial peak values for infections in MSM and IVD were never reached again. The HIV epidemic in the group of heterosexuals was mainly maintained by sexual contacts with IVD, MSM in Germany and abroad with HIV-infected persons. Autonomous heterosexual infection chains have a minor impact on the spread of the HIV epidemic in Germany.

Considering the number of reported new infections, large regional differences can be observed. Especially in densely populated urban areas (among others Rhine-Ruhr, Rhine-Main) and major cities, the incidence of new diagnoses is much higher than in the remaining regions. The highest incidence with 15 new HIV diagnoses/100,000 inhabitants was determined for Cologne, Frankfurt/M. and Berlin [92].

In 2012, almost all newly diagnosed HIV infections were caused by HIV-1 and only $0.3 \%$ by HIV-2 [92]. The prevailing subtype in Germany is HIV-1 M:B (about 85\%), like in Denmark, the Netherlands and Luxembourg [93].

\subsubsection{Europe}

In 2012, approximately 30,000 new HIV diagnoses have been reported by 30 countries of the European Union (EU) and the European Economic Area (EEA) (table 2). Most diagnoses were reported in Lithuania, Estonia, Belgium, the UK and Luxembourg [94]. In 2012, the ratio of men to women in the group of new infections was 3.2:1. Since 2006 the percentage of newly diagnosed cases has been rather stable. However, infections for which the information 'sexual contacts between men' was provided have been increasing since 2006 by $11 \%$ to now $40.4 \%$. The percentage of IVD with a newly diagnosed HIV infection has been decreasing over the same period by 7\%. In Eastern Europe i.v. drug use and heterosexual contacts represent the major routes of newly diagnosed infections (table 2).

The molecular epidemiologic data show that HIV-1 group M subtypes have different regional prevalence patterns. In Western Europe, as in the rest of the Western world, the infection with
HIV-1 M:B is predominant. The prevalence of HIV-1 subtypes and HIV-2 in European countries reflects the historic connection of these countries to the corresponding endemic regions in Africa $[12,17,93]$. In Belgium half of the infections were caused by HIV-1 M:A (Congo-Kinshasa origin). In England and France all subtypes can be found, and in Portugal and France HIV-2 circulates in addition to HIV-1 M:B and other M subtypes [23, 95]. The emergence of an HIV-1 epidemic with subtype M:F in Romania was unusual for Europe; this subtype had been imported from Angola [96]. The Baltic States and Eastern Europe have a high HIV-1 prevalence and incidence (table 2), while in Western Russia the strain HIV-1 $\mathrm{M}: \mathrm{A} / \mathrm{B}$ (CRF03_AB) is predominant [97].

\subsubsection{Africa}

Africa is the continent that is affected most by HIV infections. About 25 million people in Africa live with HIV, about 22 million of whom in Sub-Saharan Africa [89]. The estimated HIV prevalence in Africa varies widely and lies between $0.1 \%$ in Egypt and Morocco and about 27\% in Swaziland. Heterosexual contacts are the main route of infection in Africa, and sex work and sexual violence contribute significantly to the spread of the disease. Approximately one third of those infected with HIV received antiretroviral therapy in 2013 [89].

In Africa, all HIV-1M subtypes and HIV-2 are circulating, the latter especially in Guinea-Bissau, Senegal, Côte d'Ivoire and neighbouring countries as well as in Angola and Mocambique. In Southern Africa HIV-1 M:C is predominant, in West Africa HIV-1 M:A and recombinant HIV-1 M:A/G (CRF02_AG) and in Ethiopia HIV-1 M:C. In Central Africa, in the so-called Congo Basin, all known HIV-1 subtypes are found. In countries bordering the Gulf of Guinea, infections with HIV-1 group $\mathrm{O}$ and $\mathrm{N}$ viruses are observed $[12,23]$. The two patients infected with HIV-1 group $\mathrm{P}$ come from Cameroon [11]. HIV prevalence in rural areas of Central Africa can be as low as a few \%o and in urban areas can reach values of up to $30 \%$ [98]. HIV-1 M:C is the most prevalent subtype worldwide with a percentage of $30-36 \%$ of all subtypes; its rapid spread was linked to an increased virus production in humans under the influence of sex hormones [99]. 


\subsubsection{Asia}

In Asia, about 1.7 million people are living with HIV, approximately $50 \%$ of whom receive antiretroviral therapy. The number of newly diagnosed HIV infections has decreased from 2001 to 2012 by about $26 \%$. With a generally low HIV prevalence in this region, Cambodia, China and India are the countries with the highest proportion of new HIV diagnoses. The epidemic is concentrated in distinct groups with a high risk of exposure, such as MSM, sex workers, drug users and transsexuals [89]. In Asia, HIV prevalence reflects the contacts with Africa and North America. In Thailand HIV-1 M:A/E (CRF01_AE) has been spreading in the heterosexual population through sexual intercourse and HIV-1 M:B in the population of IVD (specific subtype Bt) [100]. In western India, the HIV-2 epidemic originated from the formerly Portuguese Goa [101]. The HIV-1 epidemic in India began with repatriates from Eastern and Southern Africa and was mainly caused by HIV-1 M:C [102]. In China, HIV-1 M:A, B, C and A/E (CRF01_AE) are observed, with a distinct recombinant $\mathrm{M}: \mathrm{B} / \mathrm{C}$ subtype (CRF07_BC and CRF08_BC) spreading faster than the other subtypes [17, 103]. In China, an additional new recombinant HIV (CRF59_01B) has been described which emerged from the A/E (CRF01_AE) and a B subtype $[15,104]$. This is a further indication for the continuous evolution of HIV-1 group M in humans.

\subsubsection{Australia}

In Australia, the number of new HIV diagnoses has been increasing by approximately $26 \%$ since 2003 and has reached a value of 5.4/100,000 inhabitants in 2012. The main mode of transmission is sexual contact among men [105]. In Australia, the most common subtype is HIV-1 M:B; several additional subtypes were imported mainly from Asia. At the beginning of the epidemic the prevalent subtype B strain had a defect in Nef and a lower pathogenicity [106].

\subsubsection{North America}

About 50,000 new HIV diagnoses are reported annually in the USA with an estimated prevalence of $0.23 \%$ [107]. Approximately 1.1 million people live with HIV in the USA, $25 \%$ of whom are women. The main route of transmission is sexual contact between men. About one third of all persons infected with HIV receive antiretroviral therapy [108].

In Canada, 2,062 new HIV infections were reported in 2012, the lowest number determined since introduction of the reporting system in 1996. In Canada also, MSM represent the mainly affected group. The most prevalent subtype is HIV-1 M:B; additional subtypes have been imported from Africa, Asia and South America.

The subtype B has importance because most of the HIV test systems developed in the USA are based on subtype B viruses and therefore detect this HIV subtype with high sensitivity.

The number of persons infected with HIV-1 group $\mathrm{O}$ in the USA and Canada is below 20 [22, 98]. The number of HIV-2-infected persons in the USA is reported to be 166 and is rising - part of the HIV-2-infected individuals originate from West Africa [109].

\subsubsection{South America}

In Latin America, approximately 1.3-1.9 million people are living with HIV. In Belize, Guyana and Suriname, the estimated HIV prevalence is above $1 \%$ [89]. In addition to HIV-1 M:B (and especially the Brazilian subtype Bb), HIV-1 M:A, A/E (CRF01_AE), C and $\mathrm{F}$ are prevalent [96]. Further recombinants are found in Brazil and in neighbouring countries [16]. Two other recombinant strains of the subtypes B and F (CRF12_BF and CRF17_BF) are circulating in Argentina [110].

\subsection{HIV Detection Systems}

A general distinction can be made between two principles of detection: antibody and virus detection. HIV RNA can be detected in the blood by means of a nucleic acid test (NAT) about 11 days after infection.

\subsubsection{Antibodies}

HIV antibody screening tests are used for the primary diagnosis followed by a confirmation test in the case of a reactive result in the screening assay. In addition to the ELISA (enzyme linked immunosorbent assay) or variants of this test system, particle agglutination tests are used. Approved ELISA tests contain antigens of HIV-1 group M, particularly HIV-1 M:B, group O and HIV-2. Depending on the manufacturer, additional antigens derived from the reverse transcriptase and the $\mathrm{p} 24$ protein are included in the test systems [11,111-113]. Depending on the immune response and the antibody titre, an infection can be detected serologically after 3 weeks but usually after 4-5 weeks [114]. In rare cases, HIV-infected individuals with complete immunosuppression might be HIV antibody-negative, but they have HIV-typical clinical symptoms and measurable virus titres in the blood [115].

\section{Confirmatory Test (Western blot, Immunoblot)}

Because ELISAs were developed also for the detection of low antibody levels with the highest sensitivity, false-positive results occur, especially when immune complexes are present in the serum, e.g., if individuals had been infected with other pathogens at the time of serum collection, were recently vaccinated or had a strong stimulation of the immune system. Furthermore, false-positive results were reported for individuals with autoimmune diseases or allergies and for pregnant women. Mistakes in pre-test conditioning can lead to false-positive screening tests, e.g., in the case of incomplete coagulation of the test specimen.

The Immunoblot/Western blot assay was introduced in Germany as serologic confirmatory tests, but these test systems have a lower sensitivity in the early phase of HIV infection than antibody screening tests or p24 antigen detection systems.

Only if the criteria for a positive Immunoblot/Western blot are fulfilled can the HIV infection be considered as confirmed [116]. But if an antibody test is reactive and a positive result for the specimen is obtained in the NAT with a sensitivity of $>1,000$ HIV genome copies $/ \mathrm{ml}$, the confirmatory immunoblot can be omitted and 
the HIV-infected individual be informed about the antibody and NAT results, advising the patient to seek specific medical attendance and treatment [116].

Since the information about a positive HIV finding has farreaching consequences for the infected individual, it is recommended in cases of a positive result in the initial analysis to test a second, independently taken blood sample. In the same sample the amount of viral genomes (viral load) should also be determined using NAT in order to identify the need for antiviral treatment $[116,117]$.

\subsubsection{Virus Detection}

Virus isolation in cell culture takes approximately 6 weeks and is often unsuccessful and costly. For diagnostics in blood establishments virus isolation is of no relevance.

\section{p24 Antigen}

The p24 protein forms the inner capsid. Each virus particle contains approximately 2,000 p24 molecules [118]. Detection of p24 antigen is performed using a combination of polyclonal or monoclonal antibodies, following the principle of the sandwich ELISA technique. These assays enable the detection of HIV p24 with a sensitivity of $10 \mathrm{pg} / \mathrm{ml}$ (corresponding to about $10^{5}$ virus particles/ $\mathrm{ml}$ of blood). p24 antigen detection tests or combined antigen/antibody test systems (so-called 4th generation tests) are approved and commercially available $[114,119]$.

Approximately $60-80 \%$ of seroconversions proceed without detectable p24 antigenaemia [120]. In the course of the infection, free or particle-bound p24 can be found in plasma. In some AIDS patients, high levels of p24 antigen can be observed. There is no direct correlation between the number of HIV particles determined by NAT and the p24 antigen concentration in plasma, because p24 is shed from infected cells without associated viral nucleic acid. A positive p24 antigen test result must also be confirmed. Appropriate tests are blocking/neutralisation tests or preferably NAT [116]. Most of the HIV-1 p24 antigen tests react also with the HIV-2 p25 antigen, but in some systems with reduced sensitivity.

Screening of blood donations for p24 protein in addition to HIV antibodies is not mandatory in Germany [121]. In USA the p24 antigen test has been replaced by NAT. The blood establishments are at liberty to use combined HIV antigen/antibody tests, but nevertheless all donations must be tested with NAT.

\section{NAT - Nucleic Acid Amplification Technology}

Diagnosis of an HIV infection can be performed by determining proviral DNA in cells or of viral RNA genome in plasma. For analysis of the viral load and the presence of HIV in blood donations, RNA is extracted from virus particles in plasma. Genome detection can be done either via direct amplification of defined target sequences or through the use of probes with subsequent signal amplification. Depending on the source material, NAT enables the detection of 40-100 genome equivalents $/ \mathrm{ml}$ of plasma in an individual donation [74]. One genome equivalent (ge) equals $1.7 \pm 0.1$
IU (international units, WHO HIV-1 standard) [122]. In plasma pools, virus particles can be concentrated, e.g., by ultracentrifugation or other methods [123]. For quality control and quantification, standard materials are available [124-126].

NAT systems have been developed and made commercially available that use primers binding preferentially and stringently to the genome of HIV-1 M:B; therefore, with a few exceptions, viruses of the type HIV-1 M:B are detected with the highest sensitivity. The more an HIV-1 nucleic acid sequence deviates from HIV-1 $\mathrm{M}: \mathrm{B}$, the lower the sensitivity. Depending on the test design and the target sequence, e.g. gag or LTR or integrase (IN), just HIV-1 of group $\mathrm{M}$ or also viruses from HIV-1 groups $\mathrm{M}, \mathrm{N}, \mathrm{O}$ and $\mathrm{P}$ can be detected [23, 127-130]. Taking into account the genetic variability of the HIV genome, it is advantageous and therefore has become compulsory for Germany in 2015 to use so-called dual-target amplification techniques, i.e., assays that amplify two (or more) different regions of the HIV genome [131-133].

At present, only tests from a few manufacturers are used in Germany for the screening of blood donations with commercial NAT tests. However, since 1996 several blood establishments and manufacturers of plasma derivatives have developed their own HIV amplification assays, so-called homemade or in-house assays $[123,130,134]$. In case a test system is sufficiently sensitive, e.g., by using concentration by ultracentrifugation, testing can be performed in so-called minipools of up to 92 plasma samples [71, 123]. In order to avoid contamination of the NAT assays, fully automated processing systems have been established [135]. HIV-2 RNA can be determined by real-time polymerase chain reaction [136]. For quantitative HIV-2 genome detection, commercial tests have become available in 2012 [38]. For quality control and quantification, an international standard for HIV-2 has been developed [137].

\section{Blood and Plasma Donors}

\subsection{Prevalence and Incidence in Donor Populations}

In Germany, every year approximately 7.5 million blood and plasma donations from about 3 million donors are screened. In doing so, about $100 \mathrm{HIV}$ infections are identified and reported to the Robert Koch Institute each year. The HIV prevalence among new donors has been largely stable since 2008 (6.4/100,000 donors in 2012). However, an upward trend of seroconversions was observed in repeat donors from $2008(2.6 / 100,000)$ to 2012 $(3.3 / 100,000)[138,139]$. This increase is almost entirely due to an increase in HIV infection among male repeat donors. Most of these donors have both a reactive antibody test and a positive NAT. However, every year individual donors (4 donors in 2012) are identified with very recent infections that are HIV genome-positive in the NAT but have no detectable antibody response ('NAT only'). For years, the majority of HIV-infected donors were male (83\%) and between 24 and 45 years old. Specification of a possible transmission route is only available for slightly more than $40 \%$. Almost 
in all cases there was a sexual exposure; nearly half of the infected men indicated sexual contacts with men as the most likely route of infection. Almost all of the HIV-positive donors (MSM and heterosexuals) would have been deferred from blood donation on the base of their risk of exposure. In previous years, it was noticed that a significantly higher proportion of HIV-infected persons was found in the population of plasma donors compared to whole blood donors. This difference is becoming increasingly larger in the population of repeat donors. Whereas the HIV incidence in the group of repeat whole blood donors increased between 2009 and 2012 from 1.8 to 2.8 seroconversions/100,000 donors, the incidence in the group of repeat plasma donors increased from 4.7 to 8.4 seroconversions $/ 100,000$ donors. The reasons for this increase are unclear. The site of plasma donation centres in cities may play a role as well as the higher proportion of young male plasma donors. The trend described for Germany is not observed in other countries [140].

\subsection{Definition of Exclusion Criteria}

Blood donor eligibility is regulated by the Guidelines on the Collection of Blood and Blood Components and on Use of Blood Products (Haemotherapy) [141]. Criteria are defined for the permanent or temporary deferral from donation with respect to the transmission of HIV. Permanently deferred from donation are the following:

- Persons with a confirmed HIV infection.

- Persons with non-prescribed IV or IM drug use.

- Persons whose sexual behaviour puts them at high risk (compared to the general population) of acquiring severe infectious diseases like HBV, HCV or HIV that can be transmitted by blood:

- heterosexual persons with high-risk sexual behaviour, i.e. sexual contacts with multiple sex partners,

- men who have sexual contacts with men (MSM)

- male and female sex workers.

Temporary deferral from donating blood is valid for persons :

- who entered Germany from a country or a region, where they had been continuously resident for more than 6 months, with a comparatively high prevalence of HBV, HCV, HIV or HTLV1/-2 infections,

- who had sexual contacts with persons belonging to a group with an enhanced risk of infection with $\mathrm{HBV}, \mathrm{HCV}, \mathrm{HIV}$ and/or HTLV-1/-2 (see above),

- with tattoos or body piercing.

From a scientific perspective it appears to be justified to implement a temporary deferral for those persons with a high-risk sexual behaviour that they have verifiably changed. There is currently an intensive discussion on a national and international level whether lifetime deferral of MSM and of sex workers could be replaced by a sufficient temporary deferral, taking into account the last sexual contact between men or in sex work, respectively [142-144].

\subsection{Donor Testing and Significance}

In Germany, both HIV antibody and HIV NAT testing are mandatory.

\subsubsection{HIV Antibody Testing}

Initial testing of a donation is carried out with antibody screening test systems approved in Europe according to the German Medicinal Products Act (Medizinproduktegesetz; MPG) in connection with the In Vitro Diagnostics Directive (IVD). Tests used in Germany recognise antibodies to all known HIV-1 groups and HIV-2. Reactive screening test results must be followed by a serologic confirmation test or a NAT assay. An additional second blood sample has to be investigated for confirmation of an HIV infection (see 1.4) [116]. Until the results are clarified, the donation is separated and should be preserved for additional investigations. The donor is deferred until the final results are available [117]. According to current knowledge, the vast majority of reactive HIV antibody screening test results of blood donors are non-specific, i.e. false-positive, and have other causes, e.g., immune complexes in the specimen (see 1.4).

\subsubsection{Detecting HIV RNA by NAT}

The diagnostic window period, which is between 3 and 6 weeks for antibody screening tests, can be shortened by application of NAT. Depending on the level of viraemia, the sensitivity of the assay used and the infecting HIV, an infection can be detected as early as about 11 days post infection (see also 1.4). The HIV NAT enables sensitive detection also of non-HIV-1 M:B. Reference materials for the detection of different HIV-1 genotypes are available [126].

Despite the high labour input and costs, screening with NAT is justifiable, because the majority of potential HIV transmissions by cellular blood components have been prevented through NAT in recent years [131-133, 145-148].

\section{Cost-Benefit Calculation}

In view of the high costs of NAT and the currently low incidence in blood donors, the financial investment for the elimination of infectious, but still HIV antibody-negative donations is high, but justified. The costs are estimated to be about EUR 7.5 million per HIV infectious donation discovered and eliminated. HIV NAT testing of blood donations was introduced in Germany in the spring of 2004 [146].

In several cases, NAT tests containing only primers directed against only one genome region were not able to detect HIV with mutations in the target region of the primers. To increase safety, it has been made mandatory to use at least two different target regions for donor screening (dual target NAT) [132, 133].

From a confirmed HIV-positive donation, plasma samples and, if still possible, purified lymphocytes isolated from the donation should be stored below $-20^{\circ} \mathrm{C}$ in order to have this material available for the clarification of a potential HIV transmission to recipients of prior donations. Sequence analysis of several genome re- 
gions can be used to clarify reliably an etiologic relationship of an HIV transmission by the donation $[117,149,150]$.

\subsection{Donor History Questionnaire and Donor Interview}

According to the haemotherapy guidelines, the state of health and pre-existing relevant diseases have to be assessed by using a donor history questionnaire and a confidential interview. This can help to identify and defer persons whose donation could represent a health risk to themselves or could be associated with the risk of transmitting a disease to others. For further queries and explanations a physician has to be available. The medical history should cover all issues of the donor selection criteria (exclusion criteria) of the haemotherapy guidelines. These constitute a legally binding basis for decision-making in selecting donors. Since 2015 an updated standardised donor history questionnaire is available ( $w w w$. pei.de/spenderfragebogen), and its application is recommended by Vote 41 of the German Advisory Committee Blood (Arbeitskreis Blut) [151].

Perinatally HIV-infected children who since birth have been effectively treated with antiviral drugs for years may be antibodynegative due to early suppression of HIV replication and could theoretically become potential blood donors. They may have no measurable viral load in plasma but HIV DNA in their blood cells [152]. By declaration of the HIV infection and/or disclosure of the continuous use of anti-retroviral drugs they are excluded from donating blood.

\subsection{Donor Information and Counselling}

Recommendations on how to inform a donor with positive HIV test results are given in the vote on look-back procedures of the Arbeitskreis Blut [117]. HIV-infected donors should be informed in person and in writing by the blood establishment. HIV-infected donors should be counselled and referred to a general practitioner or a specialised centre for further care. The counselling should include information about the HIV transmission routes and the possibility of antiretroviral therapy $[116,153]$ (see also 3.4 ). The information given should also include the fact that they are no longer suitable as a blood, plasma or organ donor in Germany.

In South Africa, the possibility of exceptions in cases of kidney transplantation to HIV-infected recipients is suggested [154].

Clarification of the possible origin of the donor's infection is of epidemiologic interest. Efforts should be made in the donor interview to identify the route and the cause of infection, especially in order to prevent further transmission of the HIV infection. Such data are also required for the anonymous reporting of HIV diagnoses according to the German Transfusion Act (Transfusionsgesetz) and IfSG. A template provided by the Robert Koch Institute with a standardized questionnaire simplifies clarification and supports a nationwide standardised registration system of HIV transmission modes in the donor population.

\section{Recipients}

\subsection{Prevalence and Incidence of Blood-Associated Infections and Infectious Diseases in Recipient Populations}

Prior to the introduction of compulsory testing for HIV antibodies in May and October 1985, about 1,380 haemophiliacs and about 200 transfusion recipients were infected in Germany with HIV by blood donations and plasma derivatives [155]. With the introduction of antibody screening tests and obligatory virus inactivation procedures in the production process of plasma derivatives, the number of HIV and hepatitis virus infections by transfusion declined significantly, especially in the first 2 years. Since 2004, HIV antibody testing and HIV NAT further reduced the potential HIV burden of the source material [146]. Since 1990/1991 no HIV infections have been transmitted by plasma derivatives $[131,156]$.

According to reports to the Paul Ehrlich Institute, 2 HIV transmissions by cellular blood components (red blood cell concentrates) have occurred after the introduction of NAT screening in 2004 [157]. Both transmissions were due to very recent infections and a failure of the NAT systems used. In the case of 2007, presumably a low viral load and mutations in the primer binding region were responsible for the false-negative test results [158]. Regarding the transmission reported in 2009, the HIV-positive donor sample was repeatedly tested negative with the NAT system used [131].

The risk of HIV transmission by transfusion is estimated to be very low. Based on the data on donor testing and haemovigilance in the time period between 2007 and 2010, a risk of transmission of 1 in 9.64 million donations is calculated [132]. Taking recent risk models that include specified interdonation intervals into the assessment, the remaining residual risk of an undetected infectious whole blood donation is estimated to be 1:2.4 million [159].

As recommended for HIV-infected donors, plasma and lymphocytes of the HIV-infected recipient should also be stored [117] in order to possibly clarify the origin of infection and the transmission using molecular methods (see 2.3).

\subsection{Immune Status (Resistance, Existing Immunity, Immune Response, Age, Exogenous Factors)}

There is no protective immunity against HIV. In the case of an existing infection with HIV-1 M:B, the infected individual can become superinfected with another HIV-1 M:B strain at any time [77]. An HIV-2 infection does not protect against an infection with HIV-1 and vice versa [160]. To which extent mutations ( $\Delta 32$ deletion, mutations) in the CCR5 gene of a recipient hinder a parenteral infection remains questionable $[61,161]$. In Germany, about $1 \%$ of the population carry this mutation which is therefore irrelevant from an epidemiologic point of view. Epidemiologic studies indicate that a higher HIV dose may be necessary for sexual HIV transmission to a person who is homozygous for the $\Delta 32$ deletion in the CCR5 gene. Within the first years, the course of the disease 
Table 3. Overview of the drugs available for HIV therapy - see also [171]

\begin{tabular}{|c|c|c|c|c|}
\hline $\begin{array}{l}\text { Nucleoside/nucleotide reverse } \\
\text { transcriptase inhibitors } \\
\text { (NRTI) }\end{array}$ & $\begin{array}{l}\text { Non-nucleoside reverse } \\
\text { transcriptase inhibitors } \\
\text { (NNRTI) }\end{array}$ & $\begin{array}{l}\text { Protease inhibitors } \\
\text { (PRI or PI) }\end{array}$ & $\begin{array}{l}\text { Integrase inhibitors } \\
\text { (INI) }\end{array}$ & Entry inhibitors \\
\hline Azidothymidine - Zidovudine $(1987)^{*}$ & Nevirapine (1996) & Saquinavir (1995) & Raltegravir (2007) & Enfuvirtide (T20) (2003) \\
\hline Didanosine (1991) & Efavirenz (1998) & Indinavir (1996) & Elvitegravir (2013) & Maraviroc (2007) \\
\hline Zalcitabine (1992) & Delavirdine $^{\star}(2007)$ & Ritonavir (1996) & Dolutegravir (2013) & \\
\hline Stavudine (1994) & Etravirine (2008) & Nelfinavir (1997) & & \\
\hline Lamivudine (1995) & Rilpivirine (2011) & Lopinavir + Ritonavir (2000) & & \\
\hline Abacavir (1998) & & Atazanavir (2003) & & \\
\hline Tenofovir (2001) & & Fosamprenavir (2003) & & \\
\hline \multirow[t]{2}{*}{ Emtricitabine (2003) } & & Tripanavir (2005) & & \\
\hline & & Darunavir (2006) & & \\
\hline
\end{tabular}

can be decelerated in individuals who are heterozygous for the $\Delta 32$ mutation [62]. However, individuals with the CCR5- $\Delta 32$ deletion seem to have a higher probability of developing encephalitis after infection with the West Nile virus $[162,163]$. The older a patient is at the time of infection, the higher the risk to develop immunodeficiency at an early stage of infection [164-166].

\section{HIV Vaccination}

Since 1983, attempts were made to develop a vaccine against HIV with high expenditures regarding both personnel and finances. So far all trials have been unsuccessful, although new knowledge was acquired. Therefore, it will still take many years to develop an effective and preventive vaccine $[167,168]$.

\subsection{Severity and Course of the Disease}

The course of an HIV infection is always chronic, ending fatally without antiretroviral therapy. CD4 cell disintegration and clinical symptoms can be decelerated or suppressed by antiretroviral therapy for decades [169]. In untreated HIV-1 infections, AIDS-defining symptoms appear after a mean of about 10 years, with a range of 2-25 years. HIV-2-induced AIDS becomes apparent after a mean of approximately 15 years (see 1.2). With antiviral therapy it is possible to extend the phase without or with only slight symptoms for many years $[170,171]$.

\subsection{Therapeutic Options}

Since 1987, significant progress has been achieved in the therapy of HIV infections, especially with the introduction of protease inhibitors in 1996 and of integrase inhibitors in 2007 (table 3). Drugs with different spectra of activity are applied: nucleoside (NRTIs), nucleotide (NtRTIs) and non-nucleoside analogues (NNRTIs), reverse transcriptase inhibitors combined with protease inhibitors (PI or PRI) and/or additionally a fusion or inte- grase inhibitor (INI) [172]. Further drugs are being developed [173]. Available drugs are summarised in table 3. According to the S2 guidelines, the initial therapy of HIV infection should be started with a highly effective and at the same time safe and welltolerated combination of two NRTIs with one NNRTI [171]. A combination of different active substance groups of antiviral drugs should delay the development of resistant HIV in the patient as long as possible. In Germany, it can be expected that already approximately $10-12 \%$ of therapy-naive patients are infected with drug-resistant HIV variants. So far, the percentage of patients carrying resistant HIV has remained largely stable [174]. Therefore, a genotypic resistance test should be done prior to treatment in order to avoid a reduced effectiveness of the chosen therapy $[174,175]$.

The decision for treatment should be made by both the specialised physician and the informed patient. The best long-term therapeutic results can be reached when treatment is started before the onset of symptoms of immunodeficiency. According to the guidelines, treatment should be started when the CD4+ cell count is at or fairly below 500 cells/ $\mu 1[165,176]$. In some cases, particularly in new-borns, it is indicated to start therapy early after the infection is realised, i.e., before or at the beginning of seroconversion. Also in the case of an early treatment, it is necessary to determine whether drug-resistant viruses were transmitted [177-179].

Only some of the drugs are effective against HIV-2 [180]. Medication with antiviral drugs and the effect of the drugs on viral replication can lead to the recovery of functions of the immune system and consequently to an improvement or disappearance of clinical symptoms. Up to now, elimination of HIV from the body of an infected person through therapy is not possible - the only exception is the 'Berlin patient' who has received bone marrow transplantation from a donor homozygous for the CCR5- $\Delta 32$ deletion [181].

\section{Adverse Effects}

Although a combination of three or four drugs appears to be very successful in suppressing the replication of HIV, highly active antiviral therapy (HAART) has adverse effects that can severely re- 
duce the quality of life. Furthermore, antiretroviral drugs interfere partly with each other and sometimes with other medication via the cytochrome P450 system. This has to be accounted for in patients receiving HAART [182]. Typical visible changes in the body induced by treatment with PI/PRI are lipodystrophy, especially degradation of the buccal fat pad (Bichat's fat pad) in the cheek and the subcutaneous fat of the extremities and deposition of umbilical and nuchal fat. Common side-effects include diarrhoea, insomnia, lack of concentration and inability to gain weight despite adequate food intake; also diabetes, anaemia and neurologic disorders are observed [5, 29].

At present, an optimal therapy is feasible in cases of an infection with HIV-1B and of other HIV group $M$ viruses. It should be considered that HIV-1 group O, HIV-2 and some HIV-1 group M subtypes already have natural resistance against NNRTIs and PRI $[175,180]$.

A supplementary immunotherapy with interleukins, e.g. interleukin 2 , or potentially preventive or therapeutic vaccines have not yet led to an apparent and durable improvement of the immune function and a reduction in HIV replication [168, 183-186].

\subsection{Transmissibility}

HIV can be transmitted through body fluids such as blood, plasma or serum, genital secretions and transplanted organs such as kidney, bone and cornea; infection by artificial insemination has been documented. Transmission via saliva and bite injuries has been reported in individual cases; recently a case was reported from China [187]. Open lesions can be points of entry for HIV [188]. HIV infections through needle stick injury is possible because very small amounts of blood are sufficient to infect a person, provided that virus titres are high and/or HIV-containing cells are transmitted $[189,190]$. HIV can neither be transmitted by aerosols, social contacts and stings by insects or arthropods, nor by food or water.

\subsection{Frequency of Administration, Type and Amount of Blood Products}

Blood components: Since 2004 only 2 HIV transmissions through blood components have been reported in Germany [157]. HIV is transmitted if 1 HID (equivalent to about 500-1,000 HIV particles) is present in the administered blood component [190]. There is evidence that immediate initiation of HIV post exposure prophylaxis can prevent an infection after needle stick injury in individual cases [189, 191, 192].

Plasma derivatives: Transmission of HIV by plasma derivatives occurred between 1979 and 1989 primarily via factor VIII, factor IX and prothrombin complex concentrates (PCC). HIV has never been transmitted via albumin, antithrombin III (AT-III) and i.m. or i.v. immunoglobulin preparations, not even before the introduction of specific process steps for the depletion and inactivation of viruses. The implementation of donor selection, antibody screening and inactivation procedures has made a transmission of enveloped viruses (which are comparable in their structure to HIV) no longer possible.

\section{Blood Products}

\subsection{Infectious Load of the Starting Material and Test Methods}

Due to donor selection, testing of donations for HIV antibodies and HIV-1 genome (NAT), the probability of blood and blood products to be contaminated with HIV is very low, with an estimated residual risk of below 1 in 1 million (see 2.1 and 2.3). In addition, plasma for fractionation, which is obtained by plasmapheresis, is frequently stored for an inventory hold period of at least 60 days before further processing. If an HIV infection is confirmed in a donor, earlier samples are re-tested in the context of a look-back process, and infectious donations from donors in the seroconversion phase still in stock can be discarded. This voluntary measure further reduces the theoretical viral load of plasma pools for the production of plasma derivatives.

\subsection{Methods for Removal and Inactivation of the Infectious Agent}

The production and purification of individual proteins from plasma is not sufficient to completely rem ove HIV. Therefore additional validated procedures for an effective depletion and inactivation of viruses must be applied [193]. No transmissions of HIV by plasma derivatives have been reported since the consistent implementation of effective methods for removing and inactivating viruses in the production process. Accordingly, the experimentally determined inactivation capacity of the manufacturing process is supported by epidemiologic data.

HIV is sensitive to heat and detergents (see 1.1). HIV can be inactivated by the solvent-detergent (SD) technique, with reagents such as tri-n-butyl phosphate (TNBP) and Triton X-100 or polysorbate 80 [194-196]. Pasteurisation at $60^{\circ} \mathrm{C}$ for $10 \mathrm{~h}$ reliably inactivates HIV even in the presence of stabilisers [197]. Heat treatment of lyophilized products (e.g. $80{ }^{\circ} \mathrm{C}$ for $72 \mathrm{~h}$ or $100{ }^{\circ} \mathrm{C}$ for at least $30 \mathrm{~min}$ ) inactivates $\mathrm{HIV}$, provided there is appropriate residual moisture of about 1\% [198-200].

Because of the heat sensitivity of plasma proteins the inactivation procedures must be carried out under appropriate validated conditions [201]. The product should optimally maintain its biologic activity and native conformation, while potentially contaminating viruses should be inactivated under the production conditions $[202,203]$. Treatment with $\beta$-propiolactone and UV light is effective when applied at low protein concentrations, but not in plasma [53]. The transmission of HIV by PCC preparations was not prevented by treatment with $\beta$-propiolactone [204].

Further methods for inactivation of HIV and other viruses in blood components have been developed. These are chemical (e.g. 
inactine), photodynamic (e.g. methylene blue, riboflavin) and photochemical methods (e.g. psoralen S-58) [205-211]. Clinical trials concerning the potency and tolerability of plasma treated with methylene blue, inactivated with SD or treated with amotosalen [208] and riboflavin [211] have been performed only to a limited extent [212]. A further substance to inactivate HIV in whole blood or packed red blood cells is S-303 [213]. It is suggested that production procedures should generally inactivate an infectious dose of $6 \log _{10}\left(10^{6}\right) / \mathrm{ml}$ of viruses like HIV [214], a requirement that is not achieved by some of the above mentioned procedures.

\subsection{Feasibility and Validation of Procedures for Removal/ Inactivation of the Infectious Agent}

Validation of the various removal and inactivation steps must be carried out following the actual production processes using HIV [193, 215, 216]. HIV can be propagated to sufficient amounts in cell culture, enabling the spiking of the different source materials under laboratory conditions. Individual steps have to be investigated mimicking the different production processes with regard to their virus removal or inactivation capacity by determining the infectious titres at the start and the end of each production step. Because HIV-1 and HIV-2 are considered to have identical inactivation characteristics, it is sufficient to use HIV-1 for the validation of an inactivation method. Although HIV-1 and SIVmac239 (simian immunodeficiency virus - see fig. 2) show similar properties in inactivation experiments [217], the use of SIV is not accepted.

\section{Assessment}

The occurrence of HIV in the blood and plasma donors collectives since 1979 has been leading to a continuous increase in the viral safety requirements for the production of blood components and plasma derivatives.

Since the introduction of HIV antibody testing of blood and plasma donations in 1985 and the introduction of the HIV NAT in 2004, HIV infections via blood and blood components have been becoming very rare. The initially observed diagnostic window period of 21-45 days is now reduced to about 11 days due to the introduction of HIV NAT. The residual risk of HIV transmission through erythrocyte, granulocyte and platelet concentrates, which cannot be subjected to viral inactivation/removal processes, is low and is calculated, depending on the modelling of the risk, as 1 in 1 million to 1 in 10 million donations. No HIV infection with fresh frozen plasma, which is subject to quarantine storage, has become known since 1994.

In order to enable an assessment of the viral safety of plasma derivatives, it has become mandatory to validate the capacity of the manufacturing procedures to inactivate and/or remove viruses. Only products with a high safety margin regarding HIV (and hepatitis viruses) are approved by the authorities. The validation also provides an indication of the viral safety of these products regarding so far unknown and/or newly emerging enveloped viruses.

After donor testing was introduced and validated methods for the production of plasma derivatives became mandatory, no HIV transmission have been observed with plasma derivatives since 1990/1991; currently there is no measurable residual risk of HIV transmission by plasma derivatives.

After detection of circulating HIV strains that were not detected in NAT assays due to mutation or deletion of primer-binding regions, it has become mandatory to use dual-target NAT in order to increase the safety of blood products. However, HIV is genetically variable, and there is a need for continuous research to sustain the achieved level of safety. Continuous monitoring of circulating viruses is necessary to enable the detection of emerging new variants of HIV as early as possible and to enable accordingly the adaption and improvement of HIV detection test systems.

This paper was completed on January 16, 2015 and approved by the German Advisory Committee Blood (Arbeitskreis Blut) on May 29, 2015. It was compiled by the members of the subgroup 'Assessment of Pathogens Transmissible by Blood' of the German Advisory Committee Blood (Arbeitskreis Blut):

Prof. Dr. Lutz Gürtler

Prof. Dr. Martin Aepfelbacher

Dr. Ursula Bauerfeind

PD Dr. Dr. Johannes Blümel

Prof. Dr. Reinhard Burger

Prof. Dr. Barbara Gärtner

Dr. Albrecht Gröner

Dr. Margarethe Heiden

Prof. Dr. Martin Hildebrandt

Prof. Dr. Dr. Bernd Jansen

Dr. Ruth Offergeld

Prof. Dr. Georg Pauli

Dr. Uwe Schlenkrich

Dr. Volkmar Schottstedt

Prof. Dr. Rainer Seitz

Dr. Johanna Strobel

Dr. Hannelore Willkommen.

\section{References}

1 Luciw PA: Human immunodeficiency viruses and their replication; in Fields BN (ed): Virology, 3rd ed. Philadelphia, Lippincott-Raven, 1996, pp 1881-1952.

2 Gao F, Bailes E, Robertson DL, Chen Y, Rodenburg CM, Michael SF, Cummins LB, Arthur LO, Peeters M, Shaw GM, Sharp PM, Hahn BH: Origin of HIV-1 in the chimpanzee Pan troglodytes troglodytes. Nature 1999;397:436-441.

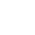
pandemic. Cold Spring Harb Perspect Med 2011; 1:a006841.

4 Faria NR, Rambant A, Suchard MA, Baele G, Bedford T, Ward MJ, Tatem AJ, Sousa JD, Arinaminpathy N, Pépin J, Posada D, Peeters M, Pybus OG, Lemey P: HIV epidemiology. The early spread and epidemic ignition of HIV-1 in human populations. Science 2014; 346:56-61.
5 Levy JA: HIV and the Pathogenesis of AIDS, 3rd ed. Washington, ASM Press, 2007.

6 Sauter D, Unterweger D, Vogl M, Usmani SM, Heigele A, Kluge SF, Hermkes E, Moll M, Barker E, Peeters M, Learn GH, Bibollet-Ruche F, Fritz JV, Fackler OT, Hahn BH, Kirchhoff F: Human tetherin exerts strong selection pressure on the HIV-1 group N Vpu protein. PLoS Pathog 2012;8:e1003093. 
7 Vincenzi E, Poli G: Novel factors interfering with human immunodeficiency virus-type 1 replication in vivo and in vitro. Tissue Antigens 2013;81:61-71.

8 Kuiken C, Leitner T, Hahn B, Mullins J, Wolinsky S, Foley B, Apetrei C, Mizrachi I, Rambaut A, Korber B: HIV Sequence Compendium 2012. Los Alamos, NM, Los Alamos National Lab. www.hiv.lanl.gov.

$\checkmark$ Simon F, Mauclère P, Roques P, Loussert-Ajaka I, Müller-Trutwin MC, Saragosti S, Georges-Courbot MC, Barré-Sinoussi F, Brun-Vézinet F: Identification of a new human immunodeficiency virus type 1 distinct from group M and group O. Nat Med 1998;4: 1032-1037.

10 Plantier JC, Leoz M, Dickerson JE, De Oliveira F, Cordonnier F, Lemée V, Damond F, Robertson DL, Simon F: A new human immunodeficiency virus derived from gorillas. Nat Med 2009;15:871-872.

11 Vallari A, Holzmayer V, Harris B, Yamaguchi J, Ngansop C, Makamche F, Mbanya D, Kaptué L, Ndembi N, Gürtler L, Devare S, Brennan CA: Confirmation of putative HIV-1 group P in Cameroon. J Virol 2011;85: 1403-1407.

12 Peeters M, Sharp PM: Genetic diversity of HIV-1: the moving target. AIDS 2000;14(suppl 3):S129-140.

13 Ward MJ, Lycett SJ, Kalish ML, Rambaut A, Leigh Brown AJ: Estimating the rate of intersubtype recombination in early HIV-1 group M strains. J Virol 2013; 87:1967-1973.

14 Chow WZ, Al-Darraji H, Lee YM, Takebe Y, Kamarulzaman A, Tee KK: Genome sequences of a novel HIV-1 CRF53_01B identified in Malaysia. J Virol 2012;86:11398-11399.

15 Jia L, Li L, Li H, Liu S, Wang X, Bao Z, Li T, Zhuang D, Liu Y, Li J: Recombination pattern reanalysis of some HIV-1 circulating recombination forms suggest the necessity and difficulty of revision. PLoS One 2014; 9:e107349.

16 Pessôa R, Watanabe JT, Calabria P, Felix AC, Loureiro P, Sabino EC, Busch MP, Sanabari SS: Deep sequencing of HIV-1 near full-length proviral genomes identifies high rates of BF1 recombinants including two novel circulating recombinant forms (CRF)70_BF1 and a disseminating 71_BF1 among blood donors in Pernambuco, Brazil. PLoS One 2014;9:e112674.

17 McCutchan FE: Understanding the genetic diversity of HIV-1. AIDS 2000;14(suppl 3):S31-S44.

18 Takehisa J, Zekeng L, Ido E, Yamaguchi-Kabata Y, Mboudjeka I, Harada Y, Miura T, Kaptué L, Hayami M: Human immunodeficiency virus type 1 intergroup (M/O) recombination in Cameroon. J Virol 1999;73: 6810-6820.

19 Gürtler LG, Hauser PH, Eberle J, von Brunn A, Knapp S, Zekeng L, Tsague JM, Kaptué L: A new subtype of human immunodeficiency virus type 1 (MVP-5180) from Cameroon. J Virol 1994;68:1581-1585.

20 Vanden Haesevelde M, Decourt JL, De Leys RJ, Vanderborght B, van der Groen G, van Heuverswijn H, Saman E: Genomic cloning and complete sequence analysis of a highly divergent African human immunodeficiency virus isolate. J Virol 1994;68:1586-1596.

21 Roques P, Robertson DL, Souquière S, Damond F, Ayouba A, Farfara I, Depienne C, Nerrienet E, Dormont D, Brun-Vézinet F, Simon F, Mauclère P: Phylogenetic analysis of 49 newly derived HIV-1 group O strains: high viral diversity but no group M-like subtype structure. Virology 2002;302:259-273.

-22 Brennan CA, Yamaguchi J, Devare SG, Foster GA, Stramer SL: Expanded evaluation of blood donors in the United States for human immunodeficiency virus type 1 non-B subtypes and antiretroviral drug-resistant strains: 2005 through 2007. Transfusion 2010;50:2707-2712.

23 Mourez T, Simon F, Plantier JC: Non-M variants of human immunodeficiency virus type 1. Clin Microbiol $\operatorname{Rev} 2013 ; 26: 448-461$
24 Gelderblom HR: Assembly and morphology of HIV: potential effect of structure on viral function. AIDS 1991;5:617-637.

25 Parren PW, Moore JP, Burton DR, Sattentau QJ: The neutralizing antibody response to HIV-1: viral evasion and escape from humoral immunity. AIDS 1999; 13(suppl A):S137-S162.

26 Niedrig M, Gelderblom HR, Pauli G, März J, Bickhard $\mathrm{H}$, Wolf $\mathrm{H}$, Modrow S: Inhibition of infectious human immunodeficiency virus type 1 particle formation by Gag protein-derived peptides. J Gen Virol 1994;75: 1469-1474.

27 Gelderblom HR, Reupke H, Pauli G: Loss of envelope antigens of HTLV-III/LAV, a factor in AIDS pathogenesis? Lancet 1985;ii:1016-1017.

28 Selhorst P, Grupping K, Tong T, Crooks ET, Martin L, Vanham G, Binley JM, Ariën KK: M48U1 CD4 mimetic has a sustained inhibitory effect on cell-associated HIV-1 by attenuating virion infectivity through gp120 shedding. Retrovirology 2013;10:12.

29 Levy JA: Virus-host interactions in HIV pathogenesis: directions for therapy. Adv Dent Res 2011;23:13-18. 30 Leonard J, Parrott C, Buckler-White AJ, Turner W, Ross EK, Martin MA, Rabson AB: The NF-kappa B binding sites in the human immunodeficiency virus type 1 long terminal repeat are not required for virus infectivity. J Virol 1989;63:4919-4924.

31 Quiñones-Mateu ME, Mas A, Lain de Lera T, Soriano V, Alcamí J, Lederman MM, Domingo E: LTR and tat variability of HIV-1 isolates from patients with divergent rates of disease progression. Virus Res 1998;57:11-20.

32 Santiago ML, Range F, Keele BF, Li Y, Bailes E, BibolletRuche F, Fruteau C, Noë R, Peeters M, Brookfield JF, Shaw GM, Sharp PM, Hahn BH: Simian immunodeficiency virus infection in free-ranging sooty mangabeys (Cercocebus atys atys) from the Taï Forest, Côte d'Ivoire: implications for the origin of epidemic human immunodeficiency virus type 2. J Virol 2005;79:12515-12527.

33 Locatelli S, Peeters M: Cross-species transmission of simian retroviruses: how and why they could lead to the emergence of new diseases in the human population. AIDS 2012;26:659-673.

34 Courgnaud V, Salemi M, Pourrut X, Mpoudi-Ngole E, Abela B, Auzel P, Bibollet-Ruche FB, Hahn B, Vandamme AM, Delaporte E, Peeters M: Characterization of a novel simian immunodeficiency virus with a $v p u$ gene from greater spot-nosed monkeys (Cercopithecus nictitans) provides new insights into simian/human immunodeficiency virus phylogeny. J Virol 2002;76:8298-8309.

35 Courgnaud V, Pourrut X, Bibollet-Ruche F, MpoudiNgole E, Bourgeois A, Delaporte E, Peeters M: Charac terization of a novel simian immunodeficiency virus from guereza colobus monkeys (Colobus guereza) in Cameroon: a new lineage in the nonhuman primate lentivirus family. J Virol 2001;75:857-866

36 Damond F, Apetrei C, Robertson DL, Souquière S, Leprêtre A, Matheron S, Plantier JC, Brun-Vézinet F, Simon F: Variability of human immunodeficiency virus type 2 (HIV-2) infecting patients living in France. Virology 2001;280:19-30.

37 Brun-Vézinet F, Charpentier C: Update on the human immunodeficiency virus. Med Mal Infect (Paris) 2013; 43:177-184.

38 Chang M, Gottlieb GS, Dragavon JA, Cherne SL, Kenney DL, Hawes SE, Smith RA, Kiviat NB, Sow PS, Coombs RW: Validation for clinical use of a novel HIV-2 plasma RNA viral load assay using the Abbott m2000 platform. J Clin Virol 2012;55:128-133.

39 Dean M, Carrington M, Winkler C, Huttley GA, Smith MW, Allikmets R, Goedert JJ, Buchbinder SP, Vittinghoff E, Gomperts E, Donfield S, Vlahov D, Kaslow R, Saah A, Rinaldo C, Detels R, O’Brien SJ: Genetic restriction of HIV-1 infection and progression to AIDS by a deletion allele of the CKR5 structural gene. Science 1996;273:1856-1862.
40 Feng Y, Broder CC, Kennedy PE, Berger EA: HIV-1 entry cofactor: functional cDNA cloning of a seventransmembrane, G protein-coupled receptor. Science 1996;272:872-877.

1 Archin NM, Sung JM, Garrido C, Soriano-Sarabia N, Margolis DM: Eradicating HIV infection: seeking to clear a persistent pathogen. Nat Rev Microbiol 2014; 12:750-764

42 Stein BS, Gowda SD, Lifson JD, Penhallow RC, Bensch KG, Engleman EG: $\mathrm{pH}$-independent HIV entry into CD4-positive $\mathrm{T}$ cells via virus envelope fusion to the plasma membrane. Cell 1987;49:659-668.

43 Sousa R, Chung YJ, Rose JP, Wang BC: Crystal structure of bacteriophage T7 RNA polymerase at $3.3 \mathrm{~A}$ resolution. Nature 1993;364:593-599.

44 Pan X, Baldauf HM, Keppler OT, Fackler OT: Restrictions to HIV-1 replication in resting CD4+ T lymphocytes. Cell Res 2013;23:876-885.

45 Moudgil T, Daar ES: Infectious decay of human immunodeficiency virus type 1 in plasma. J Infect Dis 1993; 167:210-212.

46 Perelson AS, Neumann AU, Markowitz M, Leonard JM, Ho DD: HIV-1 dynamics in vivo: virion clearance rate, infected cell life-span, and viral generation time. Science 1996;271:1582-1586

47 Zeng M, Southern PJ, Reilly CS, Beilman GJ, Chipman JG, Schacker TW, Haase AT: Lymphoid tissue damage in HIV-1 infection depletes naïve T cells and limits $\mathrm{T}$ cell reconstitution after antiretroviral therapy. PLoS Pathog 2012;8:e1002437.

48 Herbein G, Van Lint C, Lovett JL, Verdin E: Distinct mechanisms trigger apoptosis in human immunodeficiency virus type 1-infected and in uninfected bystander T lymphocytes. J Virol 1998;72:660-670.

49 Zhang YJ, Fadeel B, Hodara V, Fenyö EM: Induction of apoptosis by primary HIV-1 isolates correlates with productive infection in peripheral blood mononuclear cells. AIDS 1997;11:1219-1225.

50 Martin LS, McDougal JS, Loskoski SL: Disinfection and inactivation of the human $\mathrm{T}$ lymphotropic virus type III/lymphadenopathy-associated virus. J Infect Dis 1985; 152:400-403.

51 McDougal JS, Martin LS, Cort SP, Mozen M, Heldebrant CM, Evatt BL: Thermal inactivation of the acquired immunodeficiency syndrome virus, human Tlymphotropic virus-III/lymphadenopathy-associated virus, with special reference to antihemophilic factor. J Clin Invest 1985;76:875-877

52 Pruss A, Kao M, Kiesewetter H, von Versen R, Pauli G: Virus safety of avital bone tissue transplants: evaluation of sterilization steps of spongiosa cuboids using a peracetic acid-methanol mixture. Biologicals 1999;27: 195-201.

53 Spire B, Dormont D, Barré-Sinoussi F, Montagnier L, Chermann JC: Inactivation of lymphadenopathy-associated virus by heat, gamma rays, and ultraviolet light. Lancet 1985;i:188-189.

54 Pruss A, Kao M, Gohs U, Koscielny J, von Versen R, Pauli G: Effect of gamma irradiation on human cortical bone transplants contaminated with enveloped and non-enveloped viruses. Biologicals 2002;30:125-133.

55 Mohr H, Steil L, Gravemann U, Thiele T, Hammer E, Greinacher A, Müller TH, Völker U: A novel approach to pathogen reduction in platelet concentrates using short-wave ultraviolet light. Transfusion 2009;49: 2612-2624.

56 Kim IS, Choi YW, Kang Y, Sung HM, Shin JS: Dry-heat treatment process for enhancing viral safety of an antihemophilic factor VIII concentrate prepared from human plasma. J Microbiol Biotechnol 2008;18:997-1003.

57 Bonner K, Siemieniuk RA, Boozary A, Roberts T, Fajardo E, Cohn J: Expanding access to HIV viral load testing: a systematic review of RNA stability in EDTA tubes and PPT beyond current time and temperature thresholds. PLOS One 2014;9:e113813. 
58 Zanetti AR, Bodini U, Clerici M, Romanò L, Paolini E, Biasin M, Amendola A, Velati C: Transfusion of red blood cells from an HIV-RNA-positive/anti-HIV-negative donor without HIV infection in the recipient. Transfusion 2007;47:1328-1329.

59 Demirkhanyan L, Marin M, Lu W, Melikyan GB: Subinhibitory concentrations of human $\alpha$-defensin potentiate neutralizing antibodies against HIV-1 gp41 prehairpin intermediates in the presence of serum. PLoS Pathog 2013;9:e1003431.

60 Pauls E, Jiminez E, Ruiz A, Permanyer M, Ballana E Costa H, Nascimiento R, Parkhouse RM, Peña R, Riveiro-Muñoz E, Martinez MA, Clotet B, Esté JA, Bofill M: Restriction of HIV-1 replication in primary macrophages by IL-12 and IL-19 through the upregulation of SAMHD1. J Immunol 2013;190:4736-4741.

-61 Meng G, Wei X, Wu X, Sellers MT, Decker JM, Moldoveanu Z, Orenstein JM, Graham MF, Kappes JC, Mestecky J, Shaw GM, Smith PD: Primary intestinal epithelial cells selectively transfer R5 HIV-1 to CCR5+ cells. Nat Med 2002;8:150-156.

62 Arrildt KT, Joseph SB, Swanstrom R: The HIV-1 env protein: a coat of many colors. Curr HIV/AIDS Rep 2012;9:52-63.

63 Maher D, Wu X, Schacker T, Horbul J, Southern P: HIV binding, penetration, and primary infection in human cervicovaginal tissue. Proc Natl Acad Sci U S A 2005;102:11504-11509.

64 Grivel JC, Elliott J, Lisco A, Biancotto A, Condack C, Shattock RJ, McGowan I, Margolis L, Anton P: HIV-1 pathogenesis differs in rectosigmoid and tonsillar tissues infected ex vivo with CCR5- and CXCR4-tropic HIV-1. AIDS 2007;21:1263-1272.

65 Liuzzi G, Chirianni A, Clementi M, Bagnarelli P, Valenza A, Cataldo PT, Piazza M: Analysis of HIV-1 load in blood, semen and saliva: evidence for different viral compartments in a cross-sectional and longitudinal study. AIDS 1996;10:F51-F56.

66 Bourlet T, Cazorla C, Berthelot P, Grattard F, Cognasse F, Fresard A, Defontaine C, Lucht FR, Genin C, Pozzetto B: Compartmentalization of HIV-1 according to antiretroviral therapy: viral loads are correlated in blood and semen but poorly in blood and saliva. AIDS 2001;15:284-285.

67 Grosch-Wörner I, Schäfer A, Obladen M, Maier RF, Seel K, Feiterna-Sperling C, Weigel R: An effective and safe protocol involving zidovudine and caesarean section to reduce vertical transmission of HIV-1 infection. AIDS 2000;14:2903-2911.

68 Gibb MD, Tess BH: Interventions to reduce motherto-child transmission of HIV infection: new develop ments and current controversies. AIDS 1999;13(suppl A):S93-S102.

69 Burin des Roziers N, Sotto A, Arnaud A, Saissi G, Nasar O, Jourdan J: Kinetics of detection of antibodies to HIV-1 and plasma p24 antigens during a severe primary HIV-1 infection. AIDS 1995;9:528-529.

70 Lindbäck S, Thorstensson R, Karlsson AC, von Sydow M, Flamholc L, Blaxhult A, Sönnerborg A, Biberfeld G, Gaines H: Diagnosis of primary HIV-1 infection and duration of follow-up after HIV exposure: Karolinska Institute Primary HIV Infection Study Group. AIDS 2000;14:2333-2339.

71 Vermeulen M, Coleman C, Mitchel J, Reddy R, van Drimmelen H, Fickett T, Busch M, Lelie N: Comparison of human immunodeficiency virus assays in window phase and elite controller samples: viral load distribution and implications for transmission risk. Transfusion 2013;53:2384-2398.

72 Cockerham LR, Hatano H: Elite control of HIV: is this the right model for a functional cure? Trends Microbiol 2015;23:71-75.
Michael NL, Chang G, Kim JH, Birx DL: Dynamics of cell-free viral burden in HIV-1-infected patients. J Acquir Immune Defic Syndr Hum Retrovirol 1997;14: 237-242.

74 Schockmel GA, Yerly S, Perrin L: Detection of low HIV-1 RNA levels in plasma. J Acquir Immune Defic Syndr Hum Retrovirol 1997;14:179-183.

75 Chun TW, Shawn Justement J, Murray D, Kim CJ, Blazkova J, Hallahan CW, Benko E, Costiniuk CT, Kandel G, Ostrowski M, Kaul R, Moir S, Casazza JP, Koup RA, Kovacs C, Fauci AS: Effect of antiretroviral therapy on HIV reservoirs in elite controllers. J Infect Dis 2013;208:1443-1447.

76 Kunwar P, Hawkins N, Dinges WL, Liu Y, Gabriel EE, Swan DA, Stevens CE, Maenza J, Collier AC, Mullins JI, Hertz T, Yu X, Horton H: Superior control of HIV-1 replication by CD $8+\mathrm{T}$ cells targeting conserved epitopes: implications for HIV vaccine design. PLoS One 2013;8:e64405.

77 Altfeld M, Allen TM, Yu XG, Johnston MN, Agrawal D, Korber BT, Montefiori DC, O'Connor DH, Davis BT, Lee PK, Maier EL, Harlow J, Goulder PJ, Brander C, Rosenberg ES, Walker BD: HIV-1 superinfection despite broad CD8+ T-cell responses containing replication of the primary virus. Nature 2002;420:434-439.

78 Kong L, Sattentau QJ: Antigenicity and immunogenicity in HIV-1 antibody-based vaccine design. J AIDS Clin Res 2012;S8:3.

79 Mocroft A, Johnson MA, Phillips AN: Factors affecting survival in patients with the acquired immunodeficiency syndrome. AIDS 1996;10:1057-1065.

80 Iwuji CC, Churchill D, Gilleece Y, Weiss HA, Fisher M: Older HIV-infected individuals present late and have a higher mortality: Brighton, UK cohort study. BMC Public Health 2013;13:397.

81 Ockenga J, Tillmann HL, Trautwein C, Stoll M, Manns MP, Schmidt RE: Hepatitis B and C in HIV-infected patients. Prevalence and prognostic value. J Hepatol 1997;27:18-24.

82 Soriano V, Rodríguez-Rosado R, García-Samaniego J: Management of chronic hepatitis C in HIV-infected patients. AIDS 1999;13:539-546.

83 Soriano V, Vispo E, Fernandez-Montero JV, Labarga P, Barreiro P: Update on HIV/HCV coinfection. Curr HIV/AIDS Rep 2013;10:226-234.

84 Burbelo PD, Kovacs JA, Wagner J, Bayat A, Rhodes CS, De Souza Y, Greenspan JS, Iadarola MJ: The cancerassociated virus landscape in HIV patients with oral hairy leukoplakia, Kaposi's sarcoma, and Non-Hodgkin lymphoma. AIDS Res Treat 2012;2012:634523.

85 Brettle RP, Gore SM, Bird AG, McNeil AJ: Clinical and epidemiological implications of the Centers for Disease Control/World Health Organization reclassification of AIDS cases. AIDS 1993;7:531-539.

86 Tebit DM, Arts EJ: Tracking a century of global expansion and evolution of HIV to drive understanding and to combat disease. Lancet Infect Dis 2011;11:45-56.

87 Lemey P, Pybus OG, Wang B, Saksena NK, Salemi M, Vandamme AM: Tracing the origin and history of the HIV-2 epidemic. Proc Natl Acad Sci U S A 2003;100: 6588-6592.

88 Robbins KE, Lemey P, Pybus OG, Jaffe HW, Youngpairoj AS, Brown TM, Salemi M, Vandamme AM, Kalish ML: U.S. Human immunodeficiency virus type 1 epidemic: date of origin, population history, and characterization of early strains. J Virol 2003;77:6359-6366.

89 UNAIDS: Global report: UNAIDS report on the global AIDS epidemic 2013. www.unaids.org/en/media/unaids/ contentassets/documents/epidemiology/2013/gr2013/ UNAIDS_Global_Report_2013_en.pdf.

90 Robert Koch Institute: Schätzung der Prävalenz und Inzidenz von HIV-Infektionen in Deutschland (as of end of 2013). Epidemiol Bull 2014;44:429-437.
91 Robert Koch Institute: HIV-Infektionen und AIDSErkrankungen in Deutschland - Bericht zur Entwicklung im Jahr 2013 aus dem Robert Koch-Institut. Epidemiol Bull 2014;26:214-232.

92 Robert Koch-Institut: Infektionsepidemiologisches Jahrbuch für 2013. Berlin, Robert Koch-Institut, 2014.

93 Paraskevis D, Pybus O, Magiorkinis G, Hatzakis A, Wensing AM, van de Vijver DA, Albert J, Angarano G, Asjö B, Balotta C, Boeri E, Camacho R, Chaix ML, Coughlan S, Costagliola D, De Luca A, de Mendoza C, Derdelinckx I, Grossman Z, Hamouda O, Hoepelman I, Horban A, Korn K, Kücherer C, Leitner T, Loveday C, Macrae E, Maljkovic-Berry I, Meyer L, Nielsen C, Op de Coul EL, Ormaasen V, Perrin L, Puchhammer-Stöckl E, Ruiz L, Salminen MO, Schmit JC, Schuurman R, Soriano V, Stanczak J, Stanojevic M, Struck D, Van Laethem K, Violin M, Yerly S, Zazzi M, Boucher CA, Vandamme AM: Tracing the HIV-1 subtype B mobility in Europe: a phylogeographic approach. Retrovirology 2009;6:49.

94 European Centre for Disease Prevention and Control/ WHO Regional Office for Europe: HIV/AIDS surveillance in Europe 2012. Stockholm, European Centre for Disease Prevention and Control, 2013.

95 Dehne KL, Khodakevich L, Hamers FF, Schwartländer B: The HIV/AIDS epidemic in eastern Europe: recent patterns and trends and their implications for policymaking. AIDS 1999;13:741-749.

96 Bello G, Afonso JM, Morgado MG: Phylodynamics of HIV-1 subtype F1 in Angola, Brazil and Romania. Infect Genet Evol 2012;12:1079-1086.

97 Burruano L, Kruglov Y: HIV/AIDS epidemic in Eastern Europe: recent developments in the Russian Federation and Ukraine among women. Gend Med 2009; 6:277-289.

98 Piot P, Quinn TC: Response to the AIDS pandemic - a global health model. N Engl J Med 2013;368:2210-2218.

99 Ragupathy V, Devadas K, Tang S, Wood O, Lee S, Dastyer A, Wang X, Dayton A, Hewlett I: Effect of sex steroid hormones on replication and transmission of major HIV subtypes. J Steroid Biochem Mol Biol 2013; 138:63-71.

100 Feng Y, He X, Hsi JH, Li F, Li X, Wang Q, Ruan Y, Xing H, Lam TT, Pybus OG, Takebe Y, Shao Y: The rapidly expanding CRF01_AE epidemic in China is driven by multiple lineages of HIV-1 viruses introduced in the 1990s. AIDS 2013;27:1793-1802.

101 Schim van der Loeff MF, Aaby P: Towards a better understanding of the epidemiology of HIV-2. AIDS 1999; 13(suppl A):S69-S84.

102 Rao VR, Neogi U, Talboom JS, Padilla L, Rahman M, Fritz-French C, Gonzalez-Ramirez S, Verma A, Wood C, Ruprecht RM, Ranga U, Azim T, Joska J, Eugenin E, Shet A, Bimonte-Nelson H, Tyor WR, Prasad VR: Clade C HIV-1 isolates circulating in Southern Africa exhibit a greater frequency of dicysteine motif-containing Tat variants than those in Southeast Asia and cause increased neurovirulence. Retrovirology 2013;10:61.

103 Chen M, Yang L, Ma Y, Su Y, Yang C, Luo H, Chen H, Chen L, Yan W, Shi Y, Jia M, Lu L: Emerging variability in HIV-1 genetics among recently infected individuals in Yunnan, China. PLoS One 2013;8:e60101.

104 Han X, An M, Zhang W, Zhao B, Chu Z, Takebe Y, Shang H: Genome sequences of a novel HIV-1 circulating recombinant form (CRF59_01B) identified among men who have sex with men in Northeastern China. Genome Announc 2013;1:e00315-13.

105 The Kirby Institute: HIV, viral hepatitis and sexually transmissible infections in Australia Annual Surveillance Report 2013. Sydney, The Kirby Institute, The University of New South Wales, 2013.

106 Churchill MJ, Chiavaroli L, Wesselingh SL, Gorry PR: Persistence of attenuated HIV-1 rev alleles in an epidemiologically linked cohort of long-term survivors infected with nef-deleted virus. Retrovirology 2007;4:43. 
107 MMWR: HIV infection among heterosexuals at increased risk - United States, 2010. MMWR Morb Mortal Wkly Rep 2013;62:183-188.

108 CDC: Today's HIV/AIDS epidemic. 2015. www.cdc.gov/ nchhstp/newsroom/docs/HIVFactSheets/TodaysEpidemic508.pdf.

109 MMWR: HIV-2 infection surveillance - United States, 1987-2009. MMWR Morb Mortal Weekly Rep 2011; 60:985-988.

110 Aulicino PC, Gómez-Carrillo M, Bello G, Rocco C, Mangano A, Carr J, Sen L, Foley B: Characterization of full-length HIV-1 CRF17_BF genomes and comparison to the prototype CRF12_BF strains. Infect Genet Evol 2012;12:443-447.

111 Gürtler L, Mühlbacher A, Michl U, Hofmann H, Paggi GG, Bossi V, Thorstensson R, G-Villaescusa R, Eiras A, Hernandez JM, Melchior W, Donie F, Weber B: Reduction of the diagnostic window with a new combined p24 antigen and human immunodeficiency virus antibody screening assay. J Virol Methods 1998;75:27-38.

112 Janssen RS, Satten GA, Stramer SL, Rawal BD, O’Brien TR, Weiblen BJ, Hecht FM, Jack N, Cleghorn FR, Kahn JO, Chesney MA, Busch MP: New testing strategy to detect early HIV-1 infection for use in incidence estimates and for clinical and prevention purposes. JAMA 1998;280:42-48.

113 Kilembe W, Keeling M, Karita E, Lakhi S, Chetty P, Price MA, Makkan H, Latka M, Likoti M, Ilukui K, Hurlston M, Allen S, Stevens G, Hunter E: Failure of a novel, rapid antigen and antibody combination test to detect antigen-positive HIV infection in African adults with early HIV infection. PLoS One 2012;7:e37154.

114 Mitchell EO, Stewart G, Bajzik O, Ferret M, Bentsen C, Shriver MK: Performance comparison of the $4^{\text {th }}$ gen eration Bio-Rad Laboratories GS HIV Combo Ag/Ab EIA on the EVOLIS ${ }^{\mathrm{TM}}$ automated system versus $\mathrm{Ab}$ bott ARCHITECT HIV Ag/Ab Combo, Ortho AntiHIV $1+2$ EIA on Vitros ECi and Siemens HIV-1/O/2 enhanced on Advia Centaur. J Clin Virol 2013;58 (suppl 1):e79-84.

115 Dalmau J, Puertas MC, Azuara M, Mariño A, Frahm N, Mothe B, Izquierdo-Useros N, Buzón MJ, Paredes R, Matas L, Allen TM, Brander C, Rodrigo C, Clotet B, Martinez-Picado J: Contribution of immunological and virological factors to extremely severe primary HIV type 1 infection. Clin Infect Dis 2009;48:229-238.

116 Rabenau H, Bannert N, Berger A, Donoso Mantke O, Eberle J, Enders M, Grunert HP, Gürtler L, Heim A, Huzly D, Kaiser R, Kron K, Nick S, Kücherer C, Nübling $\mathrm{M}$, Obermeier $\mathrm{M}$, Panning $\mathrm{M}$, Zeichhardt $\mathrm{H}$ : Nachweis einer Infektion mit Humanem Immundefizienzvirus (HIV): Serologisches Screening mit nachfolgender Bestätigungsdiagnostik durch Antikörper-basierte Testsysteme und/oder durch HIV-NukleinsäureNachweis: Stellungnahme der Gemeinsamen Diagnostikkommission der Deutschen Vereinigung zur Bekämpfung von Viruskrankheiten e.V. (DVV e.V.) und der Gesellschaft für Virologie e.V. (GfV e.V.). Bundesgesundhbl Gesundheitsforsch Gesundheitsschutz 2015;58:877-886.

117 AK Blut 2006: Procedure of Look Back (pursuant to 19 Transfusion Law). At the 62nd meeting of the Work Group Blood on June 14, 2006 the following vote (V 34) was passed (in German). Bundesgesundhbl Gesundheitsforsch Gesundheitsschutz 2006;49:940-957.

118 Bourinbaiar AS, Nagorny R, Tan X: Heaviness of HIV particles in quantum relation to viral infectiousness and responsiveness to interferon; in Andrieu JM (ed): Viral Quantitation in HIV Infection. Paris, John Libbey Eurotext, 1991, pp 41-52.
119 Mühlbacher A, Schennach H, van Helden J, Hebell T, Pantaleo G, Bürgisser P, Cellerai C, Permpikul P, Rodriguez MI, Eiras A, Alborino F, Cunningham P, Axelsson M, Andersson S, Wetlitzky O, Kaiser C, Möller P, de Sousa G: Performance evaluation of a new fourthgeneration HIV combination antigen-antibody assay. Med Microbiol Immunol 2013;202:77-86.

120 Zaaijer HL, v Exel-Oehlers P, Kraaijeveld T, Altena E, Lelie PN: Early detection of antibodies to HIV-1 by third-generation assays. Lancet 1992;340:770-772.

121 AK Blut: Votum 2. Bewertung des HIV-1-p24-AntigenTest bei Blut- und Plasmaspenden. Bundesgesundhbl Gesundheitsforsch Gesundheitsschutz 1994;3:143.

122 Salles NA, Levi JE, Barreto CC, Sampaio LP, Romano CM, Sabino EC, Mendrone AJ: Human immunodeficiency virus transfusion transmission despite nucleic acid testing. Transfusion 2013;53:2593-2595.

123 Roth WK, Busch MP, Schuller A, Ismay S, Cheng A, Seed CR, Jungbauer C, Minsk PM, Sondag-Thull D, Wendel S, Levi JE, Fearon M, Delage G, Xie Y, Jukic I, Turek P, Ullum H, Tefanova V, Tilk M, Reimal R, Castren J, Naukkarinen M, Assal A, Jork C, Hourfar MK, Michel P, Offergeld R, Pichl L, Schmidt M, Schottstedt V, Seifried E, Wagner F, Weber-Schehl M, Politis C, Lin CK, Tsoi WC, O'Riordan J, Gottreich A, Shinar E, Yahalom V, Velati C, Satake M, Sanad N, Sisene L, Bon AH, Koppelmann M, Flanagan P, Flesland O, Brojer E, Lętowska M, Nascimento F, Zhiburt E, Chua SS, Teo D, Levicnik Stezinar S, Vermeulen M, Reddy R, Park Q, Castro E, Eiras A, Gonzales Fraile I, Torres P, Ekermo B, Niederhauser C, Chen H, Oota S, Brant LJ, Eglin R, Jarvis L, Mohabir L, Brodsky J, Foster G, Jennings C, Notari E, Stramer S, Kessler D, Hillyer C, Kamel H, Katz L, Taylor C, Panzer S, Reesink HW: International survey on NAT testing of blood donations: expanding implementation and yield from 1999 to 2009. Vox Sang 2012;102:82-90.

124 Holmes H, Davis C, Heath A, Hewlett I, Lelie N: An international collaborative study to establish the 1st international standard for HIV-1 RNA for use in nucleic acid-based techniques. J Virol Methods 2001;92: $141-150$.

125 Davis C, Berry N, Heath A, Holmes H: An international collaborative study to establish a replacement World Health Organization International Standard for human immunodeficiency virus 1 RNA nucleic acid assays. Vox Sang 2008;95:218-225.

126 Holmes H, Davis C, Heath A: Development of the 1st International Reference Panel for HIV-1 RNA genotypes for use in nucleic acid-based techniques. J Virol Methods 2008;154:86-91.

127 Triques K, Coste J, Perret JL, Segarra C, Mpoudi E, Reynes J, Delaporte E, Butcher A, Dreyer K, Herman S, Spadoro J, Peeters M: Efficiencies of four versions of the AMPLICOR HIV-1 MONITOR test for quantification of different subtypes of human immunodeficiency virus type 1. J Clin Microbiol 1999;37:110-116.

128 Yang C, Pieniazek D, Owen SM, Fridlund C, Nkengasong J, Mastro TD, Rayfield MA, Downing R, Biryawaho B, Tanuri A, Zekeng L, van der Groen G, Gao F, Lal RB: Detection of phylogenetically diverse human immunodeficiency virus type 1 groups $\mathrm{M}$ and $\mathrm{O}$ from plasma by using highly sensitive and specific generic primers. J Clin Microbiol 1999;37:2581-2586.

129 Wittek M, Stürmer M, Doerr HW, Berger A: Molecular assays for monitoring HIV infection and antiretroviral therapy. Expert Rev Mol Diagn 2007;7:237-246.

130 Gröner A: Pathogen safety of plasma-derived products - Haemate P/Humate-P. Haemophilia 2008;14(suppl 5):54-71.

131 Chudy M, Weber-Schehl M, Pichl L, Jork C, Kress J, Heiden M, Funk MB, Nübling CM: Blood screening nucleic acid amplification tests for human immunodeficiency virus type 1 may require two different amplification targets. Transfusion 2012;52:431-439.
132 Chudy M, Kress J, Halbauer J, Heiden M, Funk MB, Nübling CM: Risk minimization measures for blood screening HIV-1 nucleic acid amplification technique assays in Germany. Transfus Med Hemother 2014;41: 45-51.

133 Müller B, Nübling CM, Kress J, Roth WK, De Zolt S, Pichl L: How safe is safe: new human immunodeficiency virus type 1 variants missed by nucleic acid testing. Transfusion 2013;53:2422-2430.

134 Hourfar MK, Jork C, Schottstedt V, Weber-Schehl M, Brixner V, Busch MP, Geusendam G, Gubbe K, Mahnhardt C, Mayr-Wohlfart U, Pichl L, Roth WK, Schmidt M, Seifried E, Wright DJ: Experience of German Red Cross blood donor services with nucleic acid testing: results of screening more than 30 million blood donations for human immunodeficiency virus-1, hepatitis $C$ virus, and hepatitis B virus. Transfusion 2008;48:1558-1566.

135 Morel P: Ten years of nucleic acid testing: lessons and prospects. Transfus Clin Biol 2011;18:133-139.

136 Styer LM, Miller TT, Parker MM: Validation and clinical use of a sensitive HIV-2 viral load assay that uses a whole virus internal control. J Clin Virol 2013; 58(suppl 1):e127-e133.

137 Holmes H, Berry N, Heath A, Morris C: Preparation and evaluation of the 1st international standard for the quantitation of HIV-2 RNA in plasma. J Virol Methods 2011;175:246-252.

138 Robert Koch Institute: HIV-Infektionen/AIDS Schätzung der Prävalenz und Inzidenz von HIV-Infektionen in Deutschland. Zur Situation in Deutschland - Eckdaten Meldepflichtige Infektionskrankheiten: Aktuelle Statistik 43. Woche 2011. Epidemiol Bull 2011;46:415-425.

139 Robert Koch Institute: HIV-Infektion; in Infektionsepidemiologisches Jahrbuch meldepflichtiger Krankheiten für 2012. Berlin, Robert Koch-Institut, 2013, pp 111-115.

140 Bruhn R, Lelie N, Custer B, Busch M, Kleinman S Prevalence of human immunodeficiency virus RNA and antibody in first-time, lapsed, and repeat blood donations across five international regions and relative efficacy of alternative screening scenarios. Transfusion 2013;53:2399-2412.

141 Bundesärztekammer: Richtlinien zur Gewinnung von Blut und Blutbestandteilen und zur Anwendung von Blutprodukten - (Hämotherapie) - Gesamtnovelle 2005 mit Richtlinienanpassung 2010. Köln, Deutscher Ärzteverlag, 2010.

142 AK Blut: Befristete Rückstellung von der Blutspende bei Personen mit sexuellem Risikoverhalten -Stellungnahme des Arbeitskreises Blut (S12) zum Beratungsergebnis der Bundesärztekammer. 11. Juli 2013. Bundesgesundhbl Gesundheitsforsch Gesundheitsschutz 2013;56:1340-1341.

143 Bundesärztekammer: Erläuterungen und Regelungsoptionen zum Blutspende-Ausschluss bzw. zur Rückstellung von Personen, deren Sexualverhalten ein Risiko für den Empfänger von Blutprodukten birgt. 2012. www.bundesaerztekammer.de/fileadmin/user_upload/ downloads/Blutspende_24052013.pdf.

144 Offergeld R, Kamp C, Heiden M, Norda R, Behr-Gross ME: Sexual risk behaviour and donor deferral in $\mathrm{Eu}-$ rope. Vox Sang 2014;107:420-427.

145 Paul-Ehrlich-Institut: Bekanntmachung über die $\mathrm{Zu}$ lassung und Registrierung von Arzneimitteln. Verminderung des Risikos von HIV-Infektionen durch zelluläre Blutprodukte und gefrorenes Frischplasma. Bundesanzeiger 16 May 2001, 2001;90:9506-9507.

146 Nübling CM, Heiden M, Chudy M, Kress J, Seitz R, Keller-Stanislawski B, Funk MB: Experience of mandatory nucleic acid test (NAT) screening across all blood organizations in Germany: NAT yield versus breakthrough transmissions. Transfusion 2009;49:1850-1858.

147 Kleinman SH, Lelie N, Busch MP: Infectivity of human immunodeficiency virus-1, hepatitis $C$ virus, and hepatitis $\mathrm{B}$ virus and risk of transmission by transfusion. Transfusion 2009;49:2454-2489. 
148 Weusten J, Vermeulen M, van Drimmelen H, Lelie N: Refinement of a viral transmission risk model for blood donations in seroconversion window phase screened by nucleic acid testing in different pool sizes and repeat test algorithms. Transfusion 2011;51:203-215.

149 Bezemer D, van Sighem A, Lukashov VV, van der Hoek L, Back N, Schuurman R, Boucher CA, Claas EC, Boerlijst MC, Coutinho RA, de Wolf F: Transmission networks of HIV-1 among men having sex with men in the Netherlands. AIDS 2010;24:271-282.

150 Stürmer M, Zimmermann K, Fritzsche C, Reisinger E, Doelken G, Berger A, Doerr HW, Eberle J, Gürtler LG: Regional spread of HIV-1 M subtype B in middle-aged patients by random env-C2V4 region sequencing. Med Microbiol Immunol 2010;199:123-128.

151 AK Blut: Votum 41. Verwendung eines einheitlichen Fragebogens für Blut- und Plasmaspender. Bundesgesundhbl Gesundheitsforsch Gesundheitsschutz 2010; 53:862.

152 Eberle J, Notheis G, Blattmann C, Jung J, Buchholz B, Korn K, Kulozik AE, Schnitzler P: Seroreversion in vertically HIV-1-infected children treated early and efficiently: rule or exception? AIDS 2010;24:2760-2761.

153 WHO: Antiretroviral Therapy for HIV Infection in Adults and Adolescents. Recommendation for a Public health Approach, 2010 Revision. Geneva, World Health Organization, 2010.

154 Muller E, Barday Z, Mendelson M, Kahn D: HIV-positive-to-HIV-positive kidney transplantation - results at 3 to 5 years. N Engl J Med 2015;372:613-620.

155 Schramm W, Rommel F, Kopel A, Puchta R: Todesursachen und AIDS-Erkrankungen Hämophiler in Deutschland (Umfrageergebnisse 1998); in Scharrer I, Schramm W (eds): 29. Hämophilie-Symposium Hamburg 1998. Berlin, Springer, 2000, pp 7-18.

156 Unkelbach U, Hunfeld A, Breitner-Ruddock S: Prüfung von aus gepooltem Plasma hergestellten Produkten. Bundesgesundhbl Gesundheitsforsch Gesundheitsschutz 2014;57:1181-1184

157 PEI: Hämovigilanz-Bericht des Paul-Ehrlich-Instituts 2011/12: Auswertung der Meldungen von schwerwiegenden Transfusionsreaktionen nach $\$ 63 \mathrm{c}$ AMG. 2014; www.pei.de/SharedDocs/Downloads/vigilanz/ haemovigilanz/publikationen/haemovigilanz-bericht2011.pdf?_blob $=$ publicationFile\& $v=6$

158 Schmidt M, Korn K, Nübling CM, Chudy M, Kress J, Horst HA, Geusendam G, Hennig H, Sireis W, Rabenau HF, Doerr HW, Berger A, Hourfar MK, Gubbe K, Karl A, Fickenscher H, Tischer BK, Babiel R, Seifried E, Gürtler L: First transmission of human immunodeficiency virus type 1 by a cellular blood product after mandatory nucleic acid screening in Germany. Transfusion 2009;49:1836-1844.

159 an der Heiden M, Ritter S, Hamouda O, Offergeld R: Estimating the residual risk for $\mathrm{HIV}, \mathrm{HCV}$ and $\mathrm{HBV}$ in different types of platelet concentrates in Germany. Vox Sang 2015;108:123-130.

160 Norrgren H, Andersson S, Biague AJ, da Silva ZJ, Dias F, Nauclér A, Biberfeld G: Trends and interaction of HIV-1 and HIV-2 in Guinea-Bissau, west Africa: no protection of HIV-2 against HIV-1 infection. AIDS 1999, 13:701-707.

161 Parrish NF, Gao F, Li H, Giorgi EE, Barbian HJ, Parrish EH, Zajic L, Iyer SS, Decker JM, Kumar A, Hora B, Berg A, Cai F, Hopper J, Denny TN, Ding H, Ochsenbauer C, Kappes JC, Galimidi RP, West AP Jr, Bjorkman PJ, Wilen $\mathrm{CB}$, Doms RW, O'Brien M, Bhardwaj N, Borrow P, Haynes BF, Muldoon M, Theiler JP, Korber B, Shaw GM Hahn BH: Phenotypic properties of transmitted founder HIV-1. Proc Natl Acad Sci U S A 2013;110:6626-6633.

162 Loeb M, Eskandarian S, Rupp M, Fishman N, Gasink L, Patterson J, Bramson J, Hudson TJ, Lemire M: Genetic variants and susceptibility to neurological complications following West Nile virus infection. J Infect Dis 2011;204:1031-1037.
163 Pauli G, Bauerfeind U, Blümel J, Burger R, Drosten C, Gröner A, Gürtler L, Heiden M, Hildebrandt $M$, Jansen B, Montag-Lessing T, Offergeld R, Seitz R, Schlenkrich U, Schottstedt V, Strobel J, Willkommen $\mathrm{H}$ : West-Nil-Virus. Bundesgesundhbl Gesundheitsforsch Gesundheitsschutz 2012;55:1024-1043.

164 Rosenberg PS, Goedert JJ, Biggar RJ: Effect of age at seroconversion on the natural AIDS incubation distribution. Multicenter Hemophilia Cohort Study and the International Registry of Seroconverters. AIDS 1994;8: 803-810.

165 Rosenberg ES, Altfeld M, Poon SH, Phillips MN, Wilkes BM, Eldridge RL, Robbins GK, D'Aquila RT, Goulder PJ, Walker BD: Immune control of HIV-1 after early treatment of acute infection. Nature 2000; 407:523-526.

166 Aberg JA: Aging, inflammation, and HIV infection. Top Antivir Med 2012;20:101-105.

167 Stephenson KE, Barouch DH: A global approach to HIV-1 vaccine development. Immunol Rev 2013;254: 295-304.

168 Haynes BF, Moody MA, Alam M, Bonsignori M, Verkoczy L, Ferrari G, Gao F, Tomaras GD, Liao HX, Kelsoe G: Progress in HIV-1 vaccine development. J Allergy Clin Immunol 2014;134:3-10.

169 Broder S: Twenty-five years of translational medicine in antiretroviral therapy: promises to keep. Sci Transl Med 2010;2:39ps33.

170 Jaffar S, Grant AD, Whitworth J, Smith PG, Whittle H: The natural history of HIV-1 and HIV-2 infections of adults in Africa: a literature review. Bull World Health Organ 2004;82:462-469.

171 Deutsche AIDS-Gesellschaft (DAIG): Deutsch-Österreichische Leitlinien zur antiretroviralen Therapie der HIV-Infektion. www.dgi-net.de/files/Leitlinien/055001l_S2k_Antiretrovirale_Therapie_der_HIV-Infektionen_ 2012-10.pdf.

172 Wei X, Decker JM, Liu H, Zhang Z, Arani RB, Kilby JM, Saag MS, Wu X, Shaw GM, Kappes JC: Emergence of resistant human immunodeficiency virus type 1 in patients receiving fusion inhibitor (T-20) monotherapy. Antimicrob Agents Chemother 2002;46:1896-1905.

173 Esposito F, Corona A, Tramontano E: HIV-1 reverse transcriptase still remains a new drug target: structure, function, classical inhibitors, and new inhibitors with innovative mechanisms of action. Mol Biol Int 2012; 2012:586401.

174 SagirA, Oette M, Kaiser R, Däumer M, Fätkenheuer G, Rockstroh JK, Knechten H, Schmutz G, Hower M, Emmelkamp J, Pfister H, Häussinger D: Trends of prevalence of primary HIV drug resistance in Ger many. J Antimicrob Chemother 2007;60:843-848.

175 Menéndez-Arias L: Molecular basis of human immunodeficiency virus type 1 drug resistance: overview and recent developments. Antiviral Res 2013;98:93-120.

176 Hirnschall G, Harries AD, Easterbrook PJ, Doherty MC, Ball A: The next generation of the World Health Organization's global antiretroviral guidance. J Int AIDS Soc 2013;16:18757.

177 Duwe S, Brunn M, Altmann D, Hamouda O, Schmidt B, Walter H, Pauli G, Kücherer C: Frequency of genotypic and phenotypic drug-resistant HIV-1 among therapy-naive patients of the German Seroconverter Study. J Acquir Immune Defic Syndr 2001;26:266-273.

178 Vercauteren J, Wensing AM, van der Vijver DA, Albert J, Balotta C, Hamouda O, Kücherer C, Struck D, Schmit JC, Asjö B, Bruckova M, Camacho RJ, Clotet B, Coughlan S, Grossman Z, Horban A, Korn K, Kostrikis L, Nielsen C, Paraskevis D, Poljak M, PuchhammerStöckl E, Riva C, Ruiz L, Salminen M, Schuurman R, Sonnerborg A, Stanekova D, Stanojevic M, Vandamme AM, Boucher CA: Transmission of drug-resistant HIV-1 is stabilizing in Europe. J Infect Dis 2009;200: 1503-1508.
179 Geretti AM, Paredes R, Kozal MJ: Transmission of HIV drug resistance: lessons from sensitive screening assays. Curr Opin Infect Dis 2015;28:23-30.

180 Charpentier C, Camacho R, Ruelle J, Kaiser R, Eberle J, Gürtler L, Pironti A, Stürmer M, Brun-Vézinet F, Descamps D, Obermeier M: HIV-2 EU: supporting standardized HIV-2 drug resistance interpretation in Europe. Clin Infect Dis 2013;56:1654-1658.

181 Hütter G, Nowak D, Mossner M, Ganepola S, Müssig A, Allers K, Schneider T, Hoffmann J, Kücherer C, Blau O, Blau IW, Hofmann WK, Thiel E: Long-term control of HIV by CCR5 delta 32/delta 32 stem-cell transplantation. N Engl J Med 2009;360:692-698.

182 HIV Drug Interactions: HIV Drug Interaction Checker. www.hiv-druginteractions.org.

183 Blanco J, Cabrera C, Jou A, Ruiz L, Clotet B, Esté JA: Chemokine and chemokine receptor expression after combined anti-HIV-1 interleukin-2 therapy. AIDS 1999;13:547-555.

184 Goebel FD, Mannhalter JW, Belshe RB, Eibl MM, Grob PJ, de Gruttola V, Griffiths PD, Erfle V, Kunschak M, Engl W: Recombinant gp160 as a therapeutic vaccine for HIV-infection: results of a large randomized, controlled trial. AIDS 1999;13:1461-1468.

185 Carcelain G, Autran B: Immune interventions in HIV infection. Immunol Rev 2013;254:355-371.

186 Rerks-Ngarm S, Paris RM, Chunsutthiwat S, Premsri N, Namwat C, Bowonwatanuwong C, Li SS, Kaewkungkal J, Trichavaroj R, Churikanont N, de Souza MS, Andrews C, Francis D, Adams E, Flores J, Gurunathan S, Tartaglia J, O'Connell RJ, Eamsila C, Nitayaphan S, Ngauy V, Tongcharoen P, Kunasol P, Michael NL, Robb ML, Gilbert PB, Kim JH: Extended evaluation of the virologic, immunologic, and clinical course of volunteers who acquired HIV-1 infection in a phase III vaccine trial of ALVAC-HIV and AIDSVAX B/E. J Infect Dis 2013;207:1195-1205.

187 Shao J, Chen J, Shen Y, Wang J, Zhang R, Zheng Y, Liu L, Wang Z, Lu H: Identification of human immunodeficiency virus-1 (HIV-1) transmission from a 29-yearold daughter to her mother in Shanghai, China. Arch Virol 2013;158:11-17.

188 Gürtler LG, Eberle J, Bader L: HIV transmission by needle stick and eczematous lesion - three cases from Germany. Infection 1993;21:40-41.

189 Hawkins DA, Asboe D, Barlow K, Evans B: Seroconversion to HIV-1 following a needlestick injury despite combination post-exposure prophylaxis. J Infect 2001; 43:12-15.

190 Oksenhendler E, Harzic M, Le Roux JM, Rabian C, Clauvel JP: HIV infection with seroconversion after a superficial needlestick injury to the finger. $\mathrm{N}$ Engl J Med 1986;315:582.

191 Katzenstein TL, Dickmeiss E, Aladdin H, Hede A, Nielsen C, Nielsen H, Jørgensen LB, Gerstoft J: Failure to develop HIV infection after receipt of HIV-contaminated blood and postexposure prophylaxis. Ann Intern Med 2000;133:31-34

192 Al-Hajjar SH, Frayha HH, Al-Hazmi M, Batawi R, McIntosh K, Sax PE, Al-Thawadi S, Al-Jumaah S, Busch MP, Hanhauser E, Kuritzkes DR, Li JZ, Henrich TJ: Prevention of HIV-1 transmission with postexposure prophylaxis after inadvertent infected blood transfusion. AIDS 2014;28:1539-1541

193 Committee for Proprietary Medicinal Products (CPMP): Note for Guidance on Virus Validation Studies: The Design, Contribution and Interpretation of Studies Validating the Inactivation and Removal of $\mathrm{Vi}$ ruses. CPMP/BWP/268/95, 1996. www.ema.europa.eu/ docs/en_GB/document_library/Scientific_guideline/ 2009/09/WC500003684.pdf.

194 Scheidler A, Rokos K, Reuter T, Ebermann R, Pauli G: Inactivation of viruses by beta-propiolactone in human cryo poor plasma and IgG concentrates. Biologicals 1998;26:135-144 
195 Piët MP, Chin S, Prince AM, Brotman B, Cundell AM, Horowitz B: The use of tri (n-butyl) phosphate detergent mixtures to inactivate hepatitis viruses and human immunodeficiency virus in plasma and plasma's subsequent fractionation. Transfusion 1990;30:591-598.

196 Dichtelmüller HO, Biesert L, Fabbrizzi F, Gajardo R, Gröner A, von Hoegen I, Jorquera JI, Kempf C, Kreil TR, Pifat D, Osheroff W, Poelsler G: Robustness of solvent/ detergent treatment of plasma derivatives: a data collection from Plasma Protein Therapeutics Associations member companies. Transfusion 2009;49:1931-1943.

197 Mauler R, Merkle W, Hilfenhaus J: Inactivation of HTLV-III/LAV, hepatitis B and non-A/non-B viruses by pasteurization in human plasma protein preparations. Dev Biol Stand 1987;67:337-351.

198 Dichtelmüller H, Rudnick D, Breuer B, Kotitschke R, Kloft M, Darling A, Watson E, Flehmig B, Lawson S Frösner G: Improvement of virus safety of a S/D-treated factor VIII concentrate by additional dry heat treatment at 100 degrees C. Biologicals 1996;24:125-130.

199 Stadler M, Gruber G, Kannicht C, Biesert L, Radomski KU, Suhartono H, Pock K, Neisser-Svae A, Weinberger J, Römisch J, Svae TE: Characterisation of a novel high-purity, double virus inactivated von Willebrand factor and factor VIII concentrate (Wilate). Biologicals 2006;34:281-288

200 Roberts PL, Dunkerley C, McAuley A, Winkelman L: Effect of manufacturing process parameters on virus inactivation by dry heat treatment at 80 degrees $\mathrm{C}$ in factor VIII. Vox Sang 2007;92:56-63.

201 Klamroth R, Gröner A, Simon TL: Pathogen inactivation and removal methods for plasma-derived clotting factor concentrates. Transfusion 2014;54:1406-1417

202 Prince AM, Horowitz B, Brotman B: Sterilization of hepatitis and HTLV-III viruses by exposure to tri (n-butyl) phosphate and sodium cholate. Lancet 1986; i: $706-710$.
203 Schimpf K, Brackmann HH, Kreuz W, Kraus B, Haschke F, Schramm W, Moesseler J, Auerswald G, Sutor AH, Koehler K, Hellstern P, Muntean W, Scharrer I: Absence of anti-human immunodeficiency virus types 1 and 2 seroconversion after the treatment of hemophilia A or von Willebrand's disease with pasteurized factor VIII concentrate. N Engl J Med 1989;321:1148-1152.

204 Pustoslemsek P, Kloft M, Kotitschke R: Biotest position on HIV-1 seroconversions in 1990 in 11 patients, treated with beta-propiolactone/UV virus inactivated PPSB (in German). Infusionsther Transfusionsmed 1993;20:344-346.

205 Hanson CV, Riggs JL, Lennette EH: Photochemical inactivation of DNA and RNA viruses by psoralen derivatives. J Gen Virol 1978;40:345-358.

206 Alter HJ, Creagan RP, Morel PA, Wiesehahn GP, Dorman BP, Corash L, Smith GC, Popper H, Eichberg JW: Photochemical decontamination of blood components containing hepatitis $B$ and non- $A$, non- $B$ virus. Lancet 1988;ii:1446-1450.

207 Bachmann B, Knüver-Hopf J, Lambrecht B, Mohr H: Target structures for HIV-1 inactivation by methylene blue and light. J Med Virol 1995;47:172-178.

208 Singh Y, Sawyer LS, Pinkoski LS, Dupuis KW, Hsu JC, Lin L, Corash L: Photochemicl treatment of plasma with amotosalen and long-wavelength ultraviolet light inactivates pathogens while retaining coagulation function. Transfusion 2006;46:1168-1177.

209 Wagner SJ: Developing pathogen reduction technologies for RBC suspensions. Vox Sang 2011;100:112-121.

210 Purmal A, Valeri CR, Dzik W, Pivacek L, Ragno G, Lazo A, Chapman J: Process for the preparation of pathogen-inactivated RBC concentrates by using PEN110 chemistry: preclinical studies. Transfusion 2002;42:139-145.
211 Reddy HL, Doane SK, Keil SD, Marschner S, Goodrich RP: Development of a riboflavin and ultraviolet lightbased device to treat whole blood. Transfusion 2013; 53(suppl 1):131S-136S.

212 Rock G: A comparison of methods of pathogen inactivation of FFP. Vox Sang 2011;100:169-178.

213 Mufti NA, Erickson AC, North AK, Hanson D, Sawyer L, Corash LM, Lin L: Treatment of whole blood (WB) and red blood cells (RBC) with S-303 inactivates pathogens and retains in vitro quality of stored RBC. Biologicals 2010;38:14-19.

214 Goodrich RP, Custer B, Keil S, Busch M: Defining 'adequate' pathogen reduction performance for transfused blood components. Transfusion 2010;50:1827-1837.

215 AK Blut: Votum 4: Minderung des Infektionsrisikos von Blut und Blutprodukten durch optimiertes Screening von Spendern. 1994. www.rki.de/DE/Content/ Kommissionen/AK_Blut/Voten/Uebersicht/V_04/V04_ Minderung_Infektionsrisikos.html.

216 EMA/CHMP/BWP/706271/2010 Guideline on plasma-derived medicinal products, $21 \mathrm{Jul}$ 2011. www. ema.europa.eu/docs/en_GB/document_library/Scientific_ guideline/2011/07/WC500109627.pdf.

217 Yamaguchi K, Sugiyama T, Kato S, Kondo Y, Ageyama N, Kanekiyo M, Iwata M, Koyanagi Y, Yamamoto N, Honda M: A novel CD4-conjugated ultraviolet lightactivated photocatalyst inactivates HIV-1 and SIV efficiently. J Med Virol 2008;80:1322-1331.

218 Aghokeng AF, Ayouba A, Mpoudi-Ngole E, Loul S, Liegeois F, Delaporte E, Peeters M: Extensive survey on the prevalence and genetic diversity of SIVs in primate bushmeat provides insights into risks for potential new cross-species transmissions. Infect Genet Evol 2010;10:386-396.

219 Holmes EC, Nee S, Rambaut A, Garnett GP, Harvey $\mathrm{PH}$ : Revealing the history of infectious disease epidemics through phylogenetic trees. Philos Trans R Soc Lond B Biol Sci 1995;349:33-40. 